\title{
Oak morphological traits: between taxa and environmental variability
}

JEAN M. STEPHAN ${ }^{1}$, PAMELA W. TEENY ${ }^{1}$, FEDERICO VESSELLA ${ }^{2}$, and BARTOLOMEO SCHIRONE ${ }^{2}$

${ }^{1}$ Lebanese University, Faculty of Science II, Department of Life and Earth Sciences. Fanar, Lebanon.

${ }^{2}$ Dipartimento Agricoltura, Foreste, Natura ed Energia (D.A.F.N.E.), Universita` degli Studi della Tuscia, Italy.

Jean STEPHAN, First and Corresponding author email and address: dr.jeanstephan@gmail.com; jean.stephan@ul.edu.Ib

Faculty of Science II, Fanar. Biology BIdg. $5^{\text {th }}$ floor. Tel: $+(961) 3814109$

Pamela TEENY: pamela.teeny@live.com

Federico VESSELLA: vessella@unitus.it

Bartolomeo SCHIRONE: schirone@unitus.it

\section{ABSTRACT}

The seven oak species present in Lebanon show taxonomic ambiguity partly due to their great morphological variability among and within species. Very few investigations were conducted on oaks in Lebanon despite the presence of endemic species, and none tried to discriminate these according to their morphology, nor to determine subspecies or identify eventual hybrids. In this study 1328 leaves and 550 fruits were collected covering the whole range of oak species over the Lebanese territory; 24 leaf and 6 fruit traits were recorded and analyzed in order to differentiate among species, to define missing gaps for certain subspecies and to discriminate eventual hybrids and their possible parents. Environmental conditions were attributed in each sampling location to study the effect of selected environmental factors on leaf traits. PCA results showed that several leaf and fruit traits differ significantly among species, and that species leaf characteristics override the environmental influence. The interval between central nerve and apical leaf nerve, interval between apical and basal lobes, scale length and cupule diameter are the main contributors to differentiation among taxa. Oak species were grouped according to the 3 subgenus sections and species and subspecies were discriminated mainly according to fruit traits variance. Three potential hybrids were identified, with intermediate morphology or closer to one of their parents. Variation of morphological traits were discerned according to biogeographical gradients, and varied from one species to another.

Keywords: Quercus, morphometric analysis, PCA, environmental gradient, plasticity. 


\section{Introduction}

Quercus is the biggest genus of the Fagaceae family and includes approximately 600 species distributed over different habitats in the northern hemisphere (Govaerts, 2016; Yilmaz et al., 2011). Morphological variability in oaks is prominent and mainly attributed to hybridization and introgression (Viscosi et al., 2009). Oaks are wind-pollinated trees and the reproductive barriers among species are known to be weak (Gonzalez-Rodriguez et al., 2004; Tovar-Sanchez and Oyama, 2004). Thus, when oak species with similar phenological stages grow in mixed populations as they often do, hybridization occurs either among different species in the same section or sub-genus or between species of different sections within the genus Quercus (Bacilieri et al., 1996; Borazan and Babac, 2003). These phenomena in addition to the high phenotypic plasticity of oaks cause a striking morphological variability and diversity, resulting into taxonomic confusion within the genus (Jawarneh et al., 2013; Jensen et al., 1993; Ponton et al., 2004).

Several methodologies are used to distinguish oak species, including ecological differentiation (DufourDror and Ertas, 2004; Stephan et al., 2016), and molecular analysis and morphometric measurements (Gailing-Bares et al., 2012; Ishida et al., 2003; Kremer et al., 2002; Simeone et al., 2013).

The ambiguous taxonomy of oaks can be reduced through morphologic differentiation among taxa using traits of leaves or acorns; therefore many studies worldwide have concentrated on the morphometric differentiation of oak species and hybrids. Using leaf morphological traits for differentiation among taxa is a simple solution to resolve taxonomic problems. Even through molecular analysis, the sampled material is initially attributed to pre-identified taxa, following morphological key traits. With the development of electronic devices and software, leaves are the easiest parts of trees in terms of sampling and measuring; for these reasons leaves have been used in extensive biometrical studies resulting to high success in discriminating oak species (Boratynski et al., 2008; Dupouey, 1983; Kleinschmit et al., 1995; Kremer et al., 2002). Counted, observed and transformed characters were measured and analyzed. Amongst the characters that contributed the most to the variation we list: petiole length, petiole/leaf length ratio, number of intercalary veins, pubescence, sinus width, lobe depth ratio, basal shape of lamina, apical lobe width, depth of sinus between longest and lying below side lobes, number of veins between lobes, number of lobes and proportion of width of leaf blade at mid-length to maximal width.

The measurement of different morphological characters of complete acorns were also found useful to differentiate among species (Dupouey and Badeau, 1993; Jawarneh et al., 2013) or subspecies (DufourDror and Ertas, 2002). The measured traits included: cupule diameter, length and width of cupules, 
length of the part of the acorn not covered by the cupule and the length and width of scales covering the cupule as well as peduncle length.

Hybridization and introgression are common phenomena within oak species that geographically overlap and inhabit similar ecological niche. Principal Components Analysis and Cluster Analysis were applied to measured morphological traits to assess the degree of hybridization of different populations of Quercus robur L. and Quercus petraea (Matt.) Liebl. in Northern Ireland (Rushton, 1983). Gugerli et al. (2007) investigated hybridization between Quercus petraea and Quercus robur in Switzerland by classifying individuals a priori and then testing concordance between the a priori classification and the canonical discriminant analysis of the morphological traits. Standardized canonical discriminant function coefficient was also applied to analyze hybridization between different oak taxa in Mexico, where petiole length recorded the highest coefficient value (Gonzalez-Rodriguez et al., 2004). In most cases, hybrids are a mosaic of phenotypes with parental and intermediate characters (Fortini et al., 2015; Tovar-Sanchez and Oyama, 2004; Viscosi et al., 2009).

However, morphological aspects of oaks do not only change between different taxa, rather evidences have shown that morphological variability is also induced by different environmental factors that can mask this effect (Baquedano et al., 2008). The limit of phenotypic plasticity which is a key way allowing plants to adapt to changing environmental conditions remains unknown. Thus, it is crucial to determine plant functional traits in which plasticity may play a determinant role in plant response to environmental change (Gratani, 2014). This is specifically vital because it demonstrates the ability of species to adapt to any unexpected stresses implicated due to climate change, as it is confounded by the acclimatization and adaptation process as driven by both the genetic and environmental factors (Hovenden and Vander Shoor, 2003; Sardans and Penuelas, 2006).

Morphological traits may vary or not according to specific environmental factors, while in other cases traits may vary in a different manner. Sun et al. (2016) studied Quercus guyavifolia H. Lév. which grows at high elevations of the Tibet plateau and found that values for leaf area, length, and width, the ratio of leaf length to width, shape factor (leaf perimeter ${ }^{2} /$ leaf area), and petiole length and width decreased significantly with elevation and all were positively correlated with mean annual precipitation. Others traits were negatively correlated to the daily mean maximum intensity of ultraviolet (UV)-B irradiation during the growing season.

From these previous investigations, we deduce that leaf traits vary according to the most limiting environmental factor in their respective environments (i.e. ultraviolet radiation at very high elevation, slope and soil depth in mountainous regions, water in semi-arid regions, elevation in temperate and 
sub-tropical regions, shade in middle latitudes, etc.). Nonetheless, the combined effect of species variability and environmental gradient is poorly investigated.

According to Govaerts (2016), Mouterde (1966), and Tohmé and Tohmé (2014), seven oak taxa are present in Lebanon: Quercus coccifera subsp. calliprinos (Webb) Holmboe (syn. Quercus calliprinos Webb.), Quercus infectoria Olivier subsp. boissieri (Reut.) O. Schwarz (syn. Quercus boissieri Reut.), Quercus cerris L., Quercus petraea subsp. pinnatiloba C. Koch. (syn. Quercus cedrorum Kotschy), Quercus look Kotschy (syn. Quercus brantii subsp. look (Kotschy) Mouterde), Quercus ithaburensis subsp. ithaburensis Decne. and Quercus pinnatifida Gmel., proven to be Quercus kotschyana O. Schwarz (Stephan and Teeny, 2017). The latter species is not cited by Menitsky (2005) who mentioned instead the presence of Quercus libani G. Olivier, which so far we couldn't find during our survey, nor was mentioned in Lebanon by the above cited authors. We used the oak nomenclature as per the Integrated Taxonomic Information System (ITIS), however for the sake of brevity, taxa will be designated hereafter by their shorter name (respectively: $Q$. calliprinos, $Q$. infectoria, Q. cerris, $Q$. cedrorum, Q. look, $Q$. ithaburensis, and Q. kotschyana). In many cases, Lebanon is considered the limit of the area of extend of most taxa as shown in Fig. 1 (e.g. Q. petraea subsp. pinnatiloba, Q. cerris, Q. kotschyana, and Q. look). Mouterde (1966) mentioned the possible presence of hybrids between oak species in Lebanon and noted that morphologic similarity exist amongst species leading to difficulties in their differentiation. Stephan et al. (2016) analyzed the ecological characteristics of the different oak species in Lebanon, and confirmed the presence of possible hybrids particularly since many species having their realized niches overlapping along an altitudinal gradient or according to their distance from the sea.

Hence, such context is interesting to address the following questions:

- Are there leaf and acorn measurable traits allowing a sharp discrimination amongst species and hybrids, and if yes, what are the morphometric traits that contribute the most to the morphological variability of oaks?

- Does PCA allow to determine the possible parents of oak hybrids?

- Do environmental and biogeographical factors in those geographic range edge conditions, contribute in leaf traits variability in a way that masks intrinsic species variability?

- When these environmental and biogeographical factors are considered alone, which ones contribute to leaf trait variability for a defined species?

- For a certain species, what are the leaf traits that vary according to major environmental gradients, and that could be used as indicator traits exhibiting certain response to a defined environmental change? 


\section{Material and methods}

\subsection{Site selection and sampling}

Ninety five sampling sites distributed over fifty eight locations were selected, accounting the extent of occurrence and area of occupancy of each taxon. Species with restricted distribution area have the lowest sampling sites ( 5 sites as a minimum); nonetheless almost all of their respective populations were sampled, while common oak species have a bigger sampling size and their distribution range is accounted. Sampling covered all the bioclimatic niche range of every species, as cited by Abi Saleh et al. (1996) and Stephan et al. (2016). In Table A.1 in supplementary material, we illustrate the major bioclimatic characteristics for each species adapted from Stephan et al. (2016).

The sites were preferably chosen within populations in protected areas and nature reserves, or in locations with minimal anthropogenic activities whenever possible. Each site may include individuals of one or more species or hybrids (supplementary material Table A.2).

In each site, we selected 2 mature trees per taxon (whether species or potential hybrid) present in the site. Species and hybrids were identified by referring to their morphologic description and drawings as cited by Mouterde (1966). We collected at least 10 mature and healthy leaves from all sides of each tree, at $2 \mathrm{~m}$ height from the ground, and in the middle distance between the trunk and the periphery. In addition 10 complete acorns were collected when available.

\subsection{Leaf measurement traits}

The collected leaves were directly scanned, and morphological traits measured using DIGIMIZER 4. The morphological traits were adapted from Bruschi et al. (2000) and Taleshi and Babarabi (2013) as detailed below and shown in Fig. 2. Samples of scanned leaves of each taxon are shown in Fig. 3.

It should be noted that measurements that are related to the presence of lobes were not recorded for Q. calliprinos since its leaves are not lobed. The presence of dense hairs (pilosity) was also recorded as a qualitative trait for one species (Q. kotschyana).

\subsection{Fruit measurement traits}

We measured 6 morphological characteristics of all the collected acorns according to those reported by Dufour-Dror and Ertaş (2002) using a caliber with $1 \mathrm{~mm}$ accuracy; as detailed and shown in Fig. 4.

Scale length was not measured for $Q$. infectoria, $Q$. kotschyana and $Q$. cedrorum, due to the absence of protruding scales).

\subsection{Biogeographical and environmental factors}

The investigated environmental and biogeographical factors along gradients were: i) precipitation (P), ii) elevation (which combines the effect of different factors, namely temperature, relative humidity, 
incident radiation, and wind), and iii) distance from the sea (DFS) which exhibits the continentalism aspect through thermal amplitude and relative humidity and the transition from the Mediterranean to the more arid conditions of the Irano-Turanian phytogeographic region (Djamali et al., 2012). Hence, only $Q$. calliprinos and $Q$. infectoria that are distributed over a wide range according to those gradients, were analyzed. Since GPS coordinates were taken for each sampling site, elevation was recorded and distance from the sea was calculated using ArcMap. The same software was used to lay over the precipitation map, as extracted from Stephan et al (2016).

\subsection{Statistical analysis}

Since species discrimination is initially conducted according to their affiliation to the different sections within the genus Quercus, and followed further by leaf traits to discriminate amongst species within each Quercus section (Camus, 1936-1938; Denk and Grimm, 2009, 2010; Menitsky, 2005), a similar sequence is adopted in our interpretation of the results.

Before proceeding with the comparison among groups, the Bartlett Test was run to verify the homoscedasticity conditions. Once the null hypothesis was accepted, the Analysis of Variance (ANOVA) and multiple comparisons using Duncan's test were conducted with 95\% degree of confidence in order to: i) differentiate between taxa according to their morphological characteristics, ii) assign hybrids to their parents and iii) assess the variability of morphological traits over the defined gradients (elevation, P, DFS) within species showing a wide range of distribution like Q. calliprinos, Q. infectoria, Q. cerris and Q. look.

Principal Component Analysis (PCA) was used to assign the most differentiating morphological traits for both leaves and acorns, retaining those variables likely to explain the observed variance among samples, and to assess the contribution of environmental factors to the variability of leaf traits when combined to species and when considered alone. After an autoscaling pre-treatment, original variables were used to build the principal components; matrices of samples coordinates (scores) and coefficients of linear combinations among them (loadings) were achieved. Loadings express the cosine of each variable with a principal component (PC), thus, values closest to 1 or -1 , highest the importance of that variable for the PC. Boxplots with Varimax rotation where used to display PCA results.

In order to compare the means of our samples of $Q$. ithaburensis with those represented by Dufour-Dror and Ertaş (2002), one sample T-test was applied with 5\% error. 


\section{Results}

\subsection{Leaf traits}

In all the measured length traits, the lowest mean value is for $Q$. calliprinos while $Q$. cerris registered the highest mean value for most of the traits except for PL, for which $Q$. kotschyana has the highest mean. The latter exhibited an incremental gradient from the smallest $Q$. calliprinos $(0.39 \mathrm{~cm})$, followed by $Q$. look, Q. cerris, Q. infectoria, Q. cedrorum, $Q$. ithaburensis, and $Q$. kotschyana $(1.55 \mathrm{~cm})$.

A similar gradient can be defined for the ICALN where almost all species are significantly different from each other, with $Q$. calliprinos having the lowest value $(0.37 \mathrm{~cm})$, followed by $Q$. infectoria, $Q$. look, $Q$. cedrorum, Q. ithaburensis, Q. kotschyana and Q. cerris $(1.39 \mathrm{~cm})$. (Table 1).

As for leaf shape traits, RPL separated the species into 5 significantly different groups with $Q$. cerris having the lowest mean value $(0.09 \mathrm{~cm})$ and $Q$. ithaburensis having the highest $(0.22 \mathrm{~cm})$.

Q. ithaburensis is significantly wider at the base than other taxa (W0.1: $2.74 \mathrm{~cm})$, while Q. infectoria and its hybrids have significantly wider at the top than it is at the base resulting in the highest corresponding mean values for W0.9. IABL discriminates 6 species out of 7, with $Q$. cerris showing the highest values (Table 1).

In 5 out of 8 leaf traits related to lobes and sinuses, the lowest mean values are for $Q$. look and $Q$. ithaburensis in addition to $Q$. infectoria concerning LTL and SD, as the limb margins tend to be crenate rather than lobate. Concerning IBL both $Q$. look and $Q$. cerris registered the lowest values illustrating a narrower leaf base than other species. Q. kotschyana has the highest mean value for LTL $(0.79 \mathrm{~cm})$, and very close to $Q$. cerris for SD $(2.79 \mathrm{~cm})$ which is explained by the fact that these two species owe the largest lobes, and have deep sinuses. For the remaining 3 traits related to the basal pair of lobes and sinuses $Q$. ithaburensis has the highest mean value $(I B S=3.19 \mathrm{~cm}, I B L=3.51 \mathrm{~cm}$ and $D P V S=1.67 \mathrm{~cm})$ since its leaf blade base is the widest amongst the measured species. For both IBS and DPVS an incremental gradient can be noticed from $Q$. kotschyana $(1.14 \mathrm{~cm}$ and $0.4 \mathrm{~cm}$ respectively), followed by $Q$. cerris, $Q$. cedrorum, Q. look, Q. infectoria and Q. ithaburensis. NPL showed significant similarity between species, with an increasing gradient from the species with the deepest sinus and lower number of lobes $(Q$. kotschyana and $Q$. cerris) towards species with dentate and crenelated limb margins such as $Q$. infectoria and $Q$. ithaburensis (Table 1).

We considered both leaf traits and the selected environmental factors when running the PCA, and found that most leaf traits vary together, and are slightly affected by precipitation $(P)$, elevation and soil depth from one hand, while RPL and LBS are negatively correlated to (P) and elevation, and positively correlated to distance from the sea (DFS) as shown in Fig. 5. 
Yet, the contribution of environmental variability in $\%$ after Varimax Rotation for leaf traits, does not affect significantly the samples distribution on the PCA biplot. That is, once those variables are merged with the morphometric ones, their eventual discrimination power is blinded by more important variables (e.g. LL and SD for axis D1, DPVS and IBS for axes D2 as shown in supplementary material Table A.2).

Based on the analysis of contribution in percentage of different leaf traits after Varimax rotation we can conclude that LL, SD, NLC, and LW, are the most contributors to the first synthetic variable (F1). However, IBL, DPVS, W0.1, IBL, and RPL, are the most contributors to the second synthetic variable (F2).

Fig. 6 illustrates PCA biplot after the addition of the environmental variables. Species were labeled with different colored ellipses. $Q$. calliprinos is negatively correlated to all the other species and can be easily differentiated from them when it comes to leaf morphology. Q. kotschyana is the closest to $Q$. cerris while $Q$. infectoria which is different from both is closest to $Q$. look and Q. ithaburensis. Q. cedrorum, located between the two axes, shows an intermediate leaf morphology between the latter two groups. Furthermore, the large circle of $Q$. cerris indicates the high variability within this species, this variability decreases within $Q$. cedrorum followed by $Q$. infectoria to reach the least variability within $Q$. calliprinos. With the exception of the latter, the high overlapping among the species expresses the great morphological complexity within the Quercus genus.

When integrating the species under their respective subgenus or section, boxplots confirm the results of PCA; subgenus Quercus and Cerris are mostly overlapped, stating the high level of leaf morphological similarities among the belonging species, whereas the evergreen $Q$. calliprinos representing subgenus Ilex is well separated and has clear distinctive leaf traits (supplementary material Fig. A.1).

Results of the PCA show that traits of suggested hybrids are either distributed equally between their parents (e.g. Q. infectoria $\times$ cerris), in the middle between both parents (e.g. Q. infectoria $\times$ look) or are more closely to one of the two parents (e.g. Q. infectoria $\times$ ithaburensis).

When considering the environmental variables alone, regardless of the species, we found that precipitation and elevation are positively correlated, while distance from the sea and soil depth are negatively correlated to precipitation and elevation. Aspect and slope seem to have no significant effect on leaf traits variability (supplementary material Fig. A.3). Subsequently, we will only present the ANOVA results of leaf traits that are significantly affected by to elevation, distance from the sea, or precipitation, for $Q$. calliprinos and $Q$. infectoria.

PL and RPL are significantly bigger at lower elevations for $Q$. calliprinos. LW, NLC, W0.1, W0.9, IABL and ICALN show significantly higher values at elevations between 500 and $1000 \mathrm{~m}$. In all cases, the values for 
elevations above $1500 \mathrm{~m}$ recorded the highest standard deviation. For $Q$. infectoria, almost all traits (except IABL) are significantly higher at elevations between 0 and $500 \mathrm{~m}$; values decrease gradually with elevation to reach the lowest values between 1500 and 2000m (Table 2).

Most traits of $Q$. calliprinos have significant lower values at 20-30km DFS. Depending on leaf traits, higher values are either observed closer to the sea (PL, RPL, and RBS) or at 30-40km (LL, NLC, IACLN). Nonetheless, lower RBS is recorded at the most remote distance. Leaf traits of $Q$. infectoria show a general decrease in size when moving afar from the sea (Table 3).

Most leaf traits of $Q$. calliprinos showed significantly highest values for the lowest precipitation range (300-600mm). LW, NLC and IACLN showed a tendency to decrease to reach significant lower values with highest annual rainfall (1200-1500mm), while values of most measured traits didn't follow any defined trend for middle precipitation ranges (600-1200mm). In Q. infectoria almost all leaf traits displayed a similar trend, with an increase from the lowest value observed for the lowest annual rainfall amounts $(600-800 \mathrm{~mm})$ to a maximum at average annual precipitation of $1000-1200 \mathrm{~mm}$ to decrease again when precipitation amounts keep augmenting above $1200 \mathrm{~mm}$. Yet, LL, NLC, ICALN, and IAL had significant lower values for the lowest precipitation range, whereas LW, IBS, W0.1, DPVS and IBL recorded significantly the lowest values for the highest precipitation range (Table 4).

\subsection{Fruit traits}

Quercus kotschyana, Q. cedrorum and $Q$. infectoria have significantly a smaller $C L(1.22 \mathrm{~cm}, 1.32 \mathrm{~cm}$ and $1.36 \mathrm{~cm}$ respectively), while $Q$. cerris and $Q$. ithaburensis have the longest $C L(2.21 \mathrm{~cm}$ and $2.34 \mathrm{~cm}$ respectively). Quercus callliprinos is significantly different from all taxa $(1.67 \mathrm{~cm})$. Quercus cedrorum and $Q$. infectoria have significantly smaller $C D(1.79 \mathrm{~cm}$ and $1.80 \mathrm{~cm}$ respectively). Mean measured $\mathrm{FL}$ of $Q$. cedrorum is significantly smaller $(2.48 \mathrm{~cm})$. Oppositely, $Q$. ithaburensis is significantly the longest fruit $(4.44 \mathrm{~cm})$. AD is significantly the smallest for $Q$. calliprinos, $Q$. infectoria and $Q$. cedrorum $(1.47 \mathrm{~cm}$, $1.48 \mathrm{~cm}$ and $1.52 \mathrm{~cm}$ respectively), while $Q$. look has significantly the widest diameter (Table 5).

It is evident that the species of Quercus section have no scales, while Q. look and Q. calliprinos have significantly the smaller SL $(0.39 \mathrm{~cm}$ and $0.47 \mathrm{~cm}$ respectively) but with large variability (relatively large standard deviation values), $Q$. cerris $(0.87 \mathrm{~cm})$ and $Q$. ithaburensis $(1.13 \mathrm{~cm})$ having the biggest $S L$ values.

$\mathrm{CD}$ and FL were the most discriminating traits for the 7 Quercus species, while PEL was the least discriminating trait (Table 5).

Fig. 7 displays the position of different taxa according to the observation of fruit traits and shows that $Q$. cerris and $Q$. ithaburensis exhibit high morphological variability and are close to each other, and that $Q$. look, Q. cedrorum, Q. infectoria and $Q$. kotschyana are close to each other and differ from the previous. 
Q. calliprinos has intermediate position between the different species since its biplot shows that trait measurements are evenly distributed between the two other clusters regrouping $Q$. cerris and $Q$. ithaburensis from one side, and the other species form another.

When species are grouped according to their respective subgenus or section, boxplots reveal that taxa belonging to Quercus and Cerris sections are clearly distinct when it comes to fruit traits, whereas the Ilex section is in between (supplementary material Fig. A.4). Based on the analysis of contribution in percentage of different fruit traits after Varimax rotation (supplementary material Table A.3), we can conclude that cupule diameter and cupule length are the most contributors to the first synthetic variable, followed by acorn diameter, scale length and fruit length (F1 contributing 53.93\% of variability). Peduncle length is the most contributor to the second synthetic variable (F2 contributing $16.15 \%$ of variability).

Measurements of fruit traits for suggested hybrids was possible for those which bared some fruits. For the supposed hybrid between $Q$. infectoria and $Q$. ithaburensis, the mean values of measured fruit traits shown in Table 5 differed significantly from those of $Q$. infectoria in one trait (AD), and from $Q$. ithaburensis in one trait (SL), and from both in 3 traits (CL, CD and $\mathrm{FL})$.

The supposed hybrid between $Q$. cerris and $Q$. cedrorum has mean values of measured fruit traits significantly different from both supposed parents (Table 5), although its leaves show resemblance to those of $Q$. cedrorum (Table 1).

The suggested hybrid between $Q$. infectoria and $Q$. look showed values of measured fruit traits significantly different from those of $Q$. infectoria in 3 traits ( $C L, F L$ and $P L)$, and from $Q$. look in 2 traits $(C D$ and $A D)$, and from both species in 1 trait $(S L)$. Hence, fruits and leaves are similarly combining traits of both parents (Tables 1 and 5).

In supplementary material Fig. A.5 we present boxplots after Varimax rotation of fruit traits (scattered points) as distributed according to the supposed parents of each suggested hybrid. PCA results confirm those shown in Table 5, with fruit traits either closer to one the parents (e.g. Q. infectoria $\times$ look) or split between both parents (e.g. Q. infectoria $\times$ ithaburensis). The anticipated $Q$. cerris $\times$ cedrorum has most of its traits different from both species, and few similar to $Q$. cerris.

The result of one sample T-test conducted to compare the FL, CD and SL values of our samples with the single mean values for $Q$. ithaburensis subsp. ithaburensis and $Q$. ithaburensis subsp. macrolepis respectively, as presented by Dufour-Dror and Ertaş (2002) revealed that mean FL values of our samples differ significantly from those of $Q$. ithaburensis subsp. ithaburensis, whereas CD were significantly 
different from those of $\mathrm{Q}$. ithaburensis subsp. macrolepis. SL was significantly different from both subspecies, and our samples showed intermediate values (Table 6).

\section{Discussion}

Fruit measurements highlighted that $Q$. calliprinos, $Q$. infectoria and $Q$. ithaburensis are three morphologically distinct species confirming the results presented by Jawarneh et al. (2013), and affiliated to the Ilex, Quercus and Cerris sections, respectively (Camus, 1936-1938).

$Q$. kotschyana shows a resemblance with $Q$. cedrorum and $Q$. infectoria with its acorns with appressed scales largely surpassing the cupule, but a high resemblance in leaf traits with $Q$. cerris, as it was initially described by Mouterde (1966) under the name of Q. pinnatifida.

Out of the fruit morphological traits SL was able to significantly differentiate the 5 species with protruding scales except $Q$. calliprinos and $Q$. look which have significantly the smallest scales. Figure 7 (and Figure A.4 in supplementary material) separate oak taxa present in Lebanon according to their respective subgenus, highlighting that $Q$. ithaburensis, $Q$. cerris and $Q$. look are more close to each other while $Q$. infectoria is closer to $Q$. cedrorum and $Q$. kotschyana, and that $Q$. calliprinos is generally separated from all the others. Our results are in line with the classification of Camus (1936-1938) and the updated affiliation of species based on molecular analysis as suggested by Denk and Grimm (2009, 2010) and Simeone et al. (2013), to which we can add Q. kotschyana as a member of the Quercus section.

The fruits of $Q$. ithaburensis present in Lebanon clearly resembles those of subsp. ithaburensis. However, the significant differences that appeared in the results and the intermediate SL values of the Lebanese samples suggest that the Lebanese population acts as a bridge between $Q$. ithaburensis subsp. ithaburensis and $Q$. ithaburensis subsp. macrolepis following an environmental gradient (length of summer drought period) that exhibits a morphological differentiation between both subspecies (DufourDror and Ertaş, 2002, 2004). Alternatively, the significance difference in the measured morphological traits when compared to the mentioned subspecies, could possibly be the result of genetic differentiation of the species (Jawarneh et al., 2013; Menitsky, 2005).

Discrimination according to leaf traits enabled us to differentiate between species within each section. Q. calliprinos is unique in its evergreen leaf traits, and is the sole species appertaining to the llex section. Differences in leaf morphology are less striking for other taxa, especially when they exhibit large morphological variability (e.g. Q. cerris). In terms of leaf resemblance we can distinguish amongst the deciduous species 2 groups: the first including $Q$. ithaburensis, $Q$. infectoria and $Q$. look, and the second comprising Q. kotschyana, $Q$. cerris, and $Q$. cedrorum. Yet, when we coupled those differences in leaf 
traits with those of fruits, we were able to clearly cut between the different species of the same section (e.g. $Q$. ithaburensis which has fruits comparable to those of $Q$. cerris has significantly different leaf traits, belongs, along with Q. look to the Cerris section, and Q. kotschyana which has similar leaf traits as $Q$. cerris has significantly different fruit traits and is affiliated to the Quercus section, along with $Q$. infectoria and Q. cedrorum).

The combination of the key determining traits of leaves and fruits of species allowed us to identify potential hybrids. Five supposed hybrids were analyzed out of which 3 hybrids were considered as genuine: $Q$. infectoria $\times$ cerris, $Q$. infectoria $\times$ look and $Q$. infectoria $\times$ ithaburensis. These could be related to the high frequency of hybridization of $Q$. infectoria with other species (Mouterde, 1966; Menitsky, 2005). These potential hybrids showed either an intermediate value of morphological traits (Gonzalez-Rodriguez et al., 2004; Tovar-Sanchez and Oyama, 2004), similarities with one parent, or a continuum between their parents (Borazan and Babac, 2003). Other suggested hybrids were mistakenly anticipated and were found to be trees of one of either parents. The suggested hybrid between $Q$. cedrorum and $Q$. cerris has distinctive traits from both parents and other species that are found in the sampled population (e.g. Q. kotschyana and Q. infectoria), nonetheless the number of sampled trees does not allow us to confirm our results. Moreover, only in-depth molecular analysis would confirm the identified hybrids.

The variation according to acorn morphology is mostly implicated by $C D, C L, A D$ and $S L$, which converges with different studies (Dufour-Dror and Ertaş, 2002; Jawarneh et al., 2013). On the contrary, peduncle length did not implicate greatly to variation in our study, showing a divergence with the results of Dupouey and Badeau (1993) who compared Q. robur with Q. petraea.

Variation in leaf morphology is mostly implicated by LL, SD, NLC, and LW, followed by IBL, DPVS, W0.1, $\mathrm{IBL}$, and RPL, confirming previous results for similar or different species (Boratynski et al., 2008; Bruschi et al., 2000; Dupouey and Badeau, 1993; Ishida et al., 2003; Jawarneh et al., 2013; Kremer et al., 2002). Furthermore, several traits contributed greatly to variation in other investigations but didn't in this work such as NPL, LBS, WTL, IAS, IAL and An (Boratynski et al., 2008; Gailing-Bares et al., 2012; Kremer et al., 2002; Uslu and Bakis, 2014). Hence, there is no single morphological trait that enables to differentiate among all species, but rather a group of traits for specific taxa in a defined context. Similarities in leaf morphological traits among species belonging to different sections could be attributed to their large phenotypic plasticity, their respective variability according to environmental gradients and to eventual hybridization between species of both sections. 
For instance, for common species between Lebanon and Jordan like $Q$. calliprinos, $Q$. ithaburensis and $Q$. infectoria which were investigated by Jawarneh et al. (2013), the variation of leaf width and petiole length is slightly different from our results, as those species are relatively in a more arid environment when compared to Lebanon. This led us to explore the variation of leaf morphological traits according to environmental gradients.

When considering both leaf traits and environmental variability for all species combined, results showed that the contribution of environmental variability of elevation, distance from the sea, precipitation, soil depth, aspect and slope are minor, and masked by leaf traits variability. When accounting environmental factors alone, only elevation, distance from the sea and precipitation significantly affected leaf morphological traits according to a defined gradient. The effect of those factors on leaf traits was not similar for the different species.

According to elevation, the number of leaf traits that were affected vary from one species to another; only PL and RPL showed significant higher values at lower elevations $(<500 \mathrm{~m})$ for Q. calliprinos. Although other leaf traits didn't follow a similar trend, a high variability is observed above $1500 \mathrm{~m}$ elevation, where the species thrives in edge conditions and variability reflects the combined effect of other environmental factors (i.e. radiation, humidity, soil depth, aspect, etc.). Q. infectoria exhibited a clear gradient for PL, LL, LW, IAS, IBS, NCL, W0.1, DPVS and IBL decreasing always when elevation increased. Those results converge with those of Taleshi and Babarabi (2013) obtained in Iran on $Q$. brantii. This decrease in the values of several leaf traits with the increase in elevation could be the result of the combined variation of different factors such as temperature, vegetation period, humidity, $\mathrm{CO}_{2}$ concentrations and other factors that are apparently optimal at lower elevations for the studied species. Only PL, RPL, and RBS in $Q$. calliprinos decreased with an increase in distance from the sea, and therefore are in line with the trend for elevation. In other words, the species is not significantly affected by an increase in temperature amplitude. $Q$. infectoria exhibited a more consistent trend in most traits with a decrease in values when afar from the sea, meaning that the species response to decreasing amount of humidity and increased thermal amplitude by changing leaf traits. Consequently, $Q$. infectoria showed a higher plasticity than $Q$. calliprinos, and this would explain why this species is found in both the Mediterranean and Irano-Turanian phytogeographic zones, whereas Q. calliprinos which has a high polymorphism but lower plasticity and is strictly found in the Mediterranean biome (Fig. 1).

Average annual precipitation affected both species similarly, with a decrease in leaf measured traits when $\mathrm{P}$ augmented beyond $1200 \mathrm{~mm}$. This could be attributed to the fact that higher annual rainfall, occurring in higher elevations of Mount Lebanon, is mainly snowfall, accompanied with lower 
temperatures. In such particular case, the combined factors of higher elevation mask precipitation effect as a single variable. This is confirmed by the observed trends in elevation and distance from the sea. $Q$. calliprinos leaf traits didn't follow any specific trend, yet showed higher values for the lowest $P$ range (300-600mm), which could be related to the resilience of this species to drought and its capacity to thrive in Mediterranean steppe bioclimatic zone (Stephan et al., 2016). Q. infectoria manifested again a clear trend when $\mathrm{P}$ varied. This shows that each oak species has a higher phenotypic plasticity and is affected by environmental conditions differently.

The absence of a clear continuum of the variability of certain traits within a defined species suggest that many populations may have either a limited plasticity to a specific environmental factor such as previously explained for $Q$. calliprinos, or the simultaneous effect of additional environmental factors such as temperature, soil depth, rock type and slope would blur the effect of elevation, distance from the sea and precipitation when considered alone. In other cases, it could be attributed to genetic variability that is inducing changes in leaf morphology that override environmental effect. For instance sinus depth which does not follow any specific trend in $Q$. infectoria could be related to the presence of different varieties or subspecies within this taxa, as suggested by Mouterde (1966).

\section{Conclusion}

Morphological discrimination enabled us to identify the morphological characteristics of seven species

including the endemic $Q$. kotschyana. PCA of morphological traits enabled in determining three potential genuine hybrids: $Q$. infectoria $\times$ cerris, $Q$. infectoria $\times$ look, and $Q$. infectoria $\times$ ithaburensis. Molecular analysis should enable to validate our results. Cupule diameter, interval between central nerve and apical leaf nerve, interval between apical and basal lobes were able to differentiate the 7 oak taxa present in Lebanon into 6 significantly different groups based on PCA results.

There is no doubt that morphological traits are mostly affected by species, and override the effect of changes in environmental factors. Yet, elevation, distance from the sea and average annual precipitation are factors that significantly affect leaf morphology. Morphological variation showing a clear continuum could be observed in taxa exhibiting a high plasticity to certain environmental conditions. For $Q$. calliprinos, petiole length could be a good indicator to study variation according to elevation and distance from the sea, while nerve length in blade center is better indicator for precipitation gradient. For $Q$. infectoria, leaf length, nerve length in blade center, and distance of the principle vein to the sinus are indicators suitable for the three studied gradients. This paper presents the first crucial step that would be completed with genetic studies and is considered the basis for the morphological differentiation between oak taxa in Lebanon, in order to clearly distinguish between all oak taxa in 
Lebanon and to deduce the phylogeny and evolution of Levantine oaks while increasing taxonomic clarity.

\section{Acknowledgement}

Funding: This work was supported by the Lebanese University Individual research grants. Contribution of the different authors: Stephan conceived the idea and was responsible of the methodological approach and the writing, Teeny conducted the sampling and morphometric analysis, Vessella conducted the statistical analysis and provided the DIGIMIZER 4, and Schirone gave advice, remarks and amendments.

\section{References}

Abi Saleh, B., Nazih, N., Hanna, R., Safi, N., Safi, S., Tohmé, H., 1996. Etude de la diversité biologique du Liban. Flore terrestre, Tome III. MOA-UNEP.

Bacilieri, R., Ducousso, A., Petit, R.J., Kremer, A., 1996. Mating system and asymmetric hybridization in a mixed stand of European oaks. Evolution 50, 900-908.

Borazan, A., Babac, M.T., 2003. Morphometric leaf variation in oaks (Quercus) of Bolu, Turkey. Ann. Bot. Fennici. 40, 233-242.

Boratynski, A., Marcysiak, K., Lewandowska, A., Jasinka, A., Iszkulo, G., Burozyk, J., 2008. Differences in leaf morphology between Quercus petraea and Q. robur adult and young individuals. Silva Fenn. $42,15-124$

Bruschi, P., Vendramin, G.G., Bussotti, F., Grossoni, P., 2000. Morphological and molecular differentiation between Quercus petraea (Matt.) Liebl. and Quercus pubescens Willd. (Fagaceae) in Northern and Central Italy. Ann. Bot. 85, 325-333.

Camus, A., 1936-38. Les chênes. Monographie du genre Quercus et monographie du genre Lithocarpus. Encyclopédie Economique de Sylviculture. Lechevalier, Paris.

Denk, T., Grimm, G.W., 2009. Significance of pollen characteristics for infrageneric classification and phylogeny in Quercus (Fagaceae). Int. J. Plant Sci. 170, 926-940.

Denk, T., Grimm, G.W., 2010. The oaks of western Eurasia: Traditional classifications and evidence from two nuclear markers. Taxon 59, 351-366.

Djamali, M., Brewer, S., Breckle, S., Jackson, S., 2012. Climatic determinism in phytogeographic regionalization: A test from the Irano-Turanian region, SW and Central Asia. Flora 207, 237-249.

Dufour-Dror, J.M., Ertaş, M., 2002. Cupule and acorn basic morphological differences between Quercus ithaburensis Decne. subsp. ithaburensis and Quercus ithaburensis subsp. macrolepis (Kotschy) Hedge and Yalt. Acta Bot. Malacit. 27, 237-294. 
Dufour-Dror J.M., Ertaş, A., 2004. Bioclimatic perspectives in the distribution of Quercus ithaburensis Decne. subspecies in Turkey and in the Levant. J. Biogeogr. 31, 461-474.

Dupouey, J.L., Badeau, V., 1993. Morphological variability of oaks (Quercus robur L, Quercus petraea (Matt) Liebl, Quercus pubescens Willd) in northeastern France: preliminary results. Ann. Sci. 50, 35-40.

Dupouey, J.L., 1983. Analyse multivariable de quelques caractères morphologiques de populations de chênes (Quercus petraea (Matt) Liebl et Quercus robur L) du Hurepoix. Ann. Sci. For. 40, 265282.

Fortini, P., Marzio, P.D., Pietro, R.D., 2015. Differentiation and hybridization of Quercus frainetto, Q. petraea, and Q. pubescens (Fagaceae): insights from macro-morphological leaf traits and molecular data. Plant Syst. Evol. 301, 375-385.

Gailing-Bares, O., Lind, J., Lilleskov, E., 2012. Leaf morphological and genetic differentiation between Quercus rubra L. and Q. ellipsoidalis E.J. Hill populations in contrasting environments. Plant Syst. Evol. 298, 1533-1545.

Gonzalez-Rodriguez, A., Arias, D.M., Valencia, S., Oyama, K., 2004. Morphological and rapd analysis of hybridization between Quercus affinis and Q. laurina (fagaceae), two Mexican red oaks. Am. J. Bot. 91, 401-409.

Govaerts, R. (ed). For a full list of reviewers see: http://apps.kew.org/wcsp/compilersReviewers.do (2016) WCSP: World Checklist of Selected Plant Families (version Sep 2014) In: Species 2000 and ITIS Catalogue of Life, (Roskov, Y., Abucay, L., Orrell, T., Nicolson, D., Kunze, T., Flann, C., Bailly, N., Kirk, P., Bourgoin, T., DeWalt, R.E., Decock, W., De Wever, A., Eds). Digital resource at www.catalogueoflife.org/col. Species 2000: Naturalis, Leiden, the Netherlands (Accessed 26 May 2016).

Gugerli, F., Walser, J.C., Dounavi, K., Holderegger, R., Finkeldey, R., 2007. Coincidence of Small-scale Spatial Discontinuities in Leaf Morphology and Nuclear Microsatellite Variation of Quercus petraea and Q. robur in a Mixed Forest. Ann. Bot. 99, 713-722.

Ishida, T.A., Hattori, L., Sato, H., Kimura, M.T., 2003. Differentiation and hybridization between Quercus crispula and $Q$. dentata (Fagaceae): insights from morphological traits, amplified fragment length polymorphism markers, and leafminer composition. Am. J. Bot. 90, 769-776.

Jawarneh, M.S., Brake, M.H., Muhaidat, R., Migdadi, H.M., Lahham, J.N., El-Oqlah, A.A., 2013. Characterization of Quercus species distributed in Jordan using morphological and molecular markers. Afr. J. Biotechnol. 12, 1326-1334. 
Jensen, R.J., Hokanson, S.C., Isebrands, J.G., Hancock, J.F., 1993. Morphometric variation in oaks of the Apostle Islands in Wisconsin: evidence of hybridization between Quercus rubra and $Q$. ellipsoidalis (Fagaceae). Am. J. Bot. 80, 1358-1366.

Kleinschmit, J., Bacilieri, R., Kremer, A., Roloff, A., 1995. Comparison of morphological and genetic traits of pedunculate oak (Q. robur L.) and sessile oak (Q. petraea (Matt.) Liebl.). Silvae Genet. 44, 256-269.

Kremer, A., Dupouey J.L., Deans, J.D., Cottrell, J., Csaikl, U., Finkeldey, R., Espinel, S., Jensen, J., Kleinschmit, J., Van Dam, B., Ducousso, A., Forrest, I., Lopez de Heredia, U., Lowe, A.J., Tutkova, M., Munro, R.C., Steinhoff, S., Badeau, V., 2002. Leaf morphological differentiation between Quercus robur and Quercus petraea in stable across western European mixed oak stands. Ann. For. Sci. 59, 777-787.

Menitsky, Y. L., 2005. Oaks of Asia. Science Publishers, Enfield, NH.

Mouterde, P., 1966. La Nouvelle Flore du Liban et de la Syrie Tome II. Imprimerie Catholique, Beyrouth.

Rushton, B.S., 1983. An analysis of variation of leaf characters in Quercus robur L. and Quercus petraea (Matt.) Liebl. population samples from Northern Ireland. Irish Forestry 40, 52-77.

Simeone, M.C., Piredda, R., Alessio, P., Vessella, F., Schirone, B., 2013. Application of plastid and nuclear markers to DNA barcoding of Euro-Mediterranean oaks (Quercus, Fagaceae): problems, prospects and phylogenetic implications. Bot. J. Linn. Soc. 172, 478-499.

Stephan, J., Chayban, L., Vessella, F., 2016. Abiotic factors affecting oaks distribution in Lebanon. Turk. J. Bot. $40,595-609$.

Stephan, J., Teeny P., 2017. Revealing the taxonomy of an endemic oak of Lebanon. Plant Sociology 54 (2) Supp. 1: 97-100

Taleshi, H., Babarabi, M.M., 2013. Leaf morphological variation of Quercus brantii Lindl. along an altitudinal gradient in Zagros forests of Fars Province, Iran. Eur. J. Exp. Biol. 3, 463-468.

Tohmé, G., Tohmé, B., 2014. Illustrated flora of Lebanon. National Council for Scientific Research, Beirut.

Tovar-Sanchez, E., Oyama, K., 2004. Natural hybridization and hybrid zones between Quercus crassifolia and Quercus crassipes (fagaceae) in Mexico: morphological and molecular evidence. Am. J. Bot. 91, 1352-1363.

Uslu, E., Bakis, Y., 2014. Morphometric analyses of the leaf variation within Quercus L. Sect. Cerris Loudon in Turkey. Dendrobiology 71, 109-117. 
Viscosi, V., Lepais, O., Gerber, S., Fortini, P., 2009. Leaf morphological analyses in four European oak species (Quercus and their hybrids: A comparison of traditional and geometric morphometric methods. Plant Biosyst. 1-11.

Yilmaz, A., Uslu, E., Babac, M.T., 2011. Cytogenetic studies on Quercus L. (Fagaceae) species belonging to Ilex and Cerris section in Turkey. International Journal of Cytology, Cytosystematics and Cytogenetics 64, 297-301.

\section{List of Tables}

Table 1 Mean and standard deviation values for measured leaf traits (in $\mathrm{cm}$ )

Table 2 Leaf morphological traits variation (in $\mathrm{cm}$ ) according to elevation for $Q$. calliprinos and $Q$. infectoria

Table 3 Leaf morphological traits variation (in $\mathrm{cm}$ ) according to distance from the sea (DFS) for $Q$. calliprinos and $Q$. infectoria

Table 4 Leaf morphological traits variation (in $\mathrm{cm}$ ) according to average annual precipitation $(P)$ for $Q$. calliprinos and $Q$. infectoria

Table 5 Mean and standard deviation values for measured fruit traits (in $\mathrm{cm}$ )

Table 6 Fruit trait mean values (in $\mathrm{cm}$ ) of our samples of $Q$. ithaburensis and those of $Q$. ithaburensis subsp ithaburensis and Q. ithaburensis subsp macrolepis from Dufour-Dror Ertaş (2002)

\section{List of Figures}

Fig. 1 Area of distribution of the studied oak taxa

Fig. 2 Measurements represented on $Q$. kotschyana leaf

Fig. 3 Scanned leaves of different oak taxa

Fig. 4 Measurements represented on a drawing of an acorn

Fig. 5 Biplot after Varimax rotation of all variables and their respective contribution

Fig. 6 Biplot of Observations after Varimax rotation of leaf traits.

Fig. 7 Biplot of Observations after Varimax rotation of fruit traits. 

Table 1 Mean and standard deviation values for measured leaf traits (in $\mathrm{cm}$ )

\begin{tabular}{|c|c|c|c|c|c|c|c|c|c|c|c|}
\hline & $\begin{array}{l}\text { Q. } \\
\text { calliprinos }\end{array}$ & Q. look & Q. infectoria & $\begin{array}{l}\text { Q. } \\
\text { ithaburensis }\end{array}$ & Q. cedrorum & $\begin{array}{l}\text { Q. } \\
\text { kotschyana }\end{array}$ & Q. cerris & $\begin{array}{l}\text { Q. infectoriax } \\
\text { ithaburensis }\end{array}$ & $\begin{array}{l}\text { Q. infectoria } \\
\times \text { look }\end{array}$ & $\begin{array}{l}\text { Q. infectoria } \\
\times \text { cerris }\end{array}$ & $\begin{array}{l}\text { Q. cerris } x \\
\text { cedrorum }\end{array}$ \\
\hline$N$ & 280 & 120 & 230 & 100 & 108 & 100 & 320 & 20 & 10 & 20 & 10 \\
\hline Petiole length (PL) & $0.39 \pm 1.10^{a}$ & $0.72 \pm 0.34^{b c}$ & $1.18 \pm 0.44^{\text {de }}$ & $1.39 \pm 0.35^{e}$ & $1.31 \pm 0.59^{e}$ & $1.55 \pm 0.55^{f}$ & $0.84 \pm 0.38^{b c}$ & $1.24 \pm 0.45^{e}$ & $0.70 \pm 0.45^{b}$ & $0.99 \pm 0.20^{c d}$ & $0.80 \pm 0.17^{b c}$ \\
\hline $\begin{array}{l}\text { Leaf blade length } \\
\text { (LL) }\end{array}$ & $3.65 \pm 0.88^{a}$ & $6.07 \pm 1.37^{b}$ & $6.15 \pm 1.37^{b}$ & $6.53 \pm 1.004^{b c}$ & $7.61 \pm 2.13^{\mathrm{def}}$ & $8.04 \pm 1.53^{\text {ef }}$ & $9.36 \pm 2.64^{\mathrm{g}}$ & $6.26 \pm 1.95^{b}$ & $6.93 \pm 1.95^{\mathrm{bcd}}$ & $7.31 \pm 2.22^{\text {cde }}$ & $6.35 \pm 0.95^{b c}$ \\
\hline $\begin{array}{l}\text { Leaf blade width } \\
\text { at widest point } \\
\text { (LW) }\end{array}$ & $1.97 \pm 0.49^{\mathrm{a}}$ & $2.96 \pm 0.77^{b}$ & $3.18 \pm 0.79^{b}$ & $3.88 \pm 0.81^{c}$ & $3.85 \pm 1.41^{c}$ & $4.57 \pm 0.90^{d}$ & $4.93 \pm 1.51^{\mathrm{e}}$ & $3.55 \pm 1.17^{b}$ & $3.47 \pm 1.17^{b}$ & $3.14 \pm 0.67^{a}$ & $3.10 \pm 0.62^{\mathrm{a}}$ \\
\hline $\begin{array}{l}\text { Distance between } \\
\text { widest point and } \\
\text { leaf base (WB) }\end{array}$ & $1.91 \pm 0.54^{\mathrm{a}}$ & $2.74 \pm 0.79^{b}$ & $3.36 \pm 1.04^{c}$ & $2.49 \pm 0.71^{b}$ & $3.94 \pm 1.55^{d}$ & $4.18 \pm 1.05^{d}$ & $4.99 \pm 1.75^{\mathrm{e}}$ & $3.51 \pm 0.98^{b}$ & $3.41 \pm 0.98^{b}$ & $4.04 \pm 1.47^{b}$ & $3.53 \pm 0.90^{\mathrm{a}}$ \\
\hline $\begin{array}{l}\text { Nerve length in } \\
\text { blade center (NLC) }\end{array}$ & $1.12 \pm 0.29^{a}$ & $1.86 \pm 0.47^{b}$ & $1.99 \pm 0.48^{\mathrm{b}}$ & $2.29 \pm 0.43^{c}$ & $2.25 \pm 0.76^{c}$ & $2.71 \pm 0.48^{d}$ & $2.98 \pm 0.85^{\mathrm{e}}$ & $2.10 \pm 0.67^{a}$ & $2.16 \pm 0.59^{a}$ & $2.09 \pm 0.51^{\mathrm{a}}$ & $1.86 \pm 0.40^{\mathrm{a}}$ \\
\hline $\begin{array}{l}\text { Interval between } \\
\text { central nerve and } \\
\text { apical leaf nerve } \\
\text { (ICALN) }\end{array}$ & $0.37 \pm 0.12^{\mathrm{a}}$ & $0.77 \pm 0.26^{c}$ & $0.65 \pm 0.20^{\mathrm{b}}$ & $0.86 \pm 0.26^{d}$ & $0.82 \pm 0.27^{\mathrm{cd}}$ & $0.97 \pm 0.31^{\mathrm{e}}$ & $1.37 \pm 0.53^{f}$ & $0.65 \pm 0.24^{a}$ & $0.81 \pm 0.13^{b}$ & $0.86 \pm 0.33^{b}$ & $0.71 \pm 0.17^{a}$ \\
\hline $\begin{array}{l}\text { Interval between } \\
\text { apical and basal } \\
\text { lobe( IABL) }\end{array}$ & $2.26 \pm 1.70^{\mathrm{a}}$ & $4.75 \pm 1.35^{\mathrm{bc}}$ & $4.55 \pm 1.23^{b}$ & $5.13 \pm 1.36^{c}$ & $5.62 \pm 1.74^{d}$ & $6.17 \pm 1.33^{\mathrm{e}}$ & $7.68 \pm 2.47^{f}$ & $4.97 \pm 1.68^{\mathrm{ab}}$ & $5.93 \pm 1.34^{b}$ & $4.58 \pm 1.60^{\mathrm{a}}$ & $0.52 \pm 0.98^{\mathrm{a}}$ \\
\hline $\begin{array}{l}\text { Relative petiole } \\
\text { length (RPL) }\end{array}$ & $0.11 \pm 0.03^{b}$ & $0.11 \pm 0.05^{b}$ & $0.19 \pm 0.07^{d}$ & $0.21 \pm 0.06^{\mathrm{e}}$ & $0.16 \pm 0.05^{c}$ & $0.18 \pm 0.05^{d}$ & $0.08 \pm 0.04^{\mathrm{a}}$ & $0.21 \pm 0.09^{a}$ & $0.10 \pm 0.02^{b}$ & $0.14 \pm 0.05^{b}$ & $0.13 \pm 0.03^{b}$ \\
\hline $\begin{array}{l}\text { Relative blade } \\
\text { shape (RBS) }\end{array}$ & $1.86 \pm 0.34^{c}$ & $2.04 \pm 0.30^{d}$ & $1.93 \pm 0.27^{c}$ & $1.67 \pm 0.24^{\mathrm{a}}$ & $2.003 \pm 0.33^{d}$ & $1.74 \pm 0.20^{\mathrm{b}}$ & $1.90 \pm 0.31^{c}$ & $1.77 \pm 0.15^{\mathrm{a}}$ & $2.02 \pm 0.22^{\mathrm{a}}$ & $2.35 \pm 0.65^{b}$ & $2.07 \pm 0.19^{\mathrm{a}}$ \\
\hline $\begin{array}{l}\text { Leaf basal shape } \\
\text { (LBS) }\end{array}$ & $0.59 \pm 0.09^{c}$ & $0.58 \pm 0.09^{c}$ & $0.55 \pm 0.10^{b}$ & $0.70 \pm 0.11^{d}$ & $0.45 \pm 0.13^{\mathrm{a}}$ & $0.44 \pm 0.09^{a}$ & $0.43 \pm 0.13^{\mathrm{a}}$ & $0.52 \pm 0.09^{a}$ & $0.57 \pm 0.12^{\mathrm{a}}$ & $0.50 \pm 0.31^{b}$ & $0.51 \pm 0.11^{b}$ \\
\hline $\begin{array}{l}\text { Leaf apical shape } \\
\text { (LAS) }\end{array}$ & $0.48 \pm 0.08^{e}$ & $0.32 \pm 0.11^{b}$ & $0.46 \pm 0.11^{d}$ & $0.33 \pm 0.07^{b}$ & $0.36 \pm 0.10^{c}$ & $0.31 \pm 0.09^{b}$ & $0.29 \pm 0.09^{\mathrm{a}}$ & $0.51 \pm 0.08^{c}$ & $0.45 \pm 0.06^{a}$ & $0.42 \pm 0.11^{\mathrm{a}}$ & $0.36 \pm 0.07^{a}$ \\
\hline $\begin{array}{l}\text { Blade width in } 0.1 \\
\text { length of blade } \\
\text { from leaf base } \\
\text { (W0.1) }\end{array}$ & $1.16 \pm 0.29^{a}$ & $1.72 \pm 0.56^{b}$ & $1.77 \pm 0.55^{b}$ & $2.74 \pm 0.88^{d}$ & $1.67 \pm 0.67^{b}$ & $2.006 \pm 0.59^{c}$ & $2.12 \pm 0.89^{c}$ & $1.91 \pm 0.83^{\mathrm{ab}}$ & $2.03 \pm 0.77^{a}$ & $1.54 \pm 0.74^{\mathrm{a}}$ & $1.61 \pm 0.54^{\mathrm{a}}$ \\
\hline $\begin{array}{l}\text { Blade width } 0.9 \\
\text { length of blade } \\
\text { from leaf base } \\
\text { (w0.9) }\end{array}$ & $0.96 \pm 0.29^{a}$ & $0.96 \pm 0.39^{b}$ & $1.48 \pm 0.50^{d}$ & $1.33 \pm 0.46^{b}$ & $1.43 \pm 0.69^{b}$ & $1.44 \pm 0.48^{c}$ & $1.45 \pm 0.68^{c}$ & $1.88 \pm 0.75^{b}$ & $1.54 \pm 0.36^{\mathrm{a}}$ & $1.32 \pm 0.45^{\mathrm{a}}$ & $1.13 \pm 0.34^{\mathrm{a}}$ \\
\hline $\begin{array}{l}\text { Angle of the base } \\
\text { of leaf blade (An) }\end{array}$ & $71.6 \pm 21.5^{a}$ & $102.2 \pm 25.4^{c}$ & $104.5 \pm 20.3^{c}$ & $82.4 \pm 17.8^{b}$ & $122.6 \pm 17.5^{\mathrm{e}}$ & $112.3 \pm 11^{d}$ & $105.7 \pm 26^{c}$ & $103.4 \pm 21.7^{b}$ & $96.3 \pm 14.1^{\mathrm{a}}$ & $123 \pm 22.8^{b}$ & $93.34 \pm 31.9^{\mathrm{a}}$ \\
\hline $\begin{array}{l}\text { Interval between } \\
\text { apical pair of } \\
\text { sinuses (IAS) }\end{array}$ & & $0.54 \pm 0.22^{\mathrm{a}}$ & $0.60 \pm 0.26^{\mathrm{ab}}$ & $0.81 \pm 0.27^{\text {bcde }}$ & $0.78 \pm 0.31^{\text {bcde }}$ & $0.73 \pm 0.22^{\mathrm{abcd}}$ & $0.96 \pm 0.41^{d}$ & $0.84 \pm 0.31^{\text {cde }}$ & $0.79 \pm 0.31^{\text {bcde }}$ & $0.95 \pm 0.25^{\mathrm{a}}$ & $0.71 \pm 0.25^{\mathrm{abc}}$ \\
\hline $\begin{array}{l}\text { Interval between } \\
\text { apical pair of }\end{array}$ & & $0.87 \pm 0.35^{a}$ & $0.98 \pm 0.38^{\mathrm{ab}}$ & $1.17 \pm 0.37^{b}$ & $1.49 \pm 0.64^{\mathrm{de}}$ & $1.66 \pm 0.51^{\mathrm{e}}$ & $1.70 \pm 0.77^{\mathrm{e}}$ & $1.21 \pm 0.45^{\mathrm{abc}}$ & $1.26 \pm 0.45^{\mathrm{bc}}$ & $1.45 \pm 0.38^{\mathrm{de}}$ & $1.13 \pm 0.42^{\mathrm{abc}}$ \\
\hline
\end{tabular}




\begin{tabular}{|c|c|c|c|c|c|c|c|c|c|c|c|}
\hline & $\begin{array}{l}\text { Q. } \\
\text { calliprinos }\end{array}$ & Q. look & Q. infectoria & $\begin{array}{l}\text { Q. } \\
\text { ithaburensis }\end{array}$ & Q. cedrorum & $\begin{array}{l}\text { Q. } \\
\text { kotschyana }\end{array}$ & Q. cerris & $\begin{array}{l}\text { Q. infectoriax } \\
\text { ithaburensis }\end{array}$ & $\begin{array}{l}\text { Q. infectoria } \\
\times \text { look }\end{array}$ & $\begin{array}{l}\text { Q. infectoria } \\
\times \text { cerris }\end{array}$ & $\begin{array}{l}\text { Q. cerris } x \\
\text { cedrorum }\end{array}$ \\
\hline \multicolumn{12}{|l|}{ lobes (IAL) } \\
\hline $\begin{array}{l}\text { Interval between } \\
\text { basal pair of } \\
\text { sinuses (IBS) }\end{array}$ & & $1.83 \pm 0.6^{\mathrm{bcd}}$ & $3.20 \pm 0.74^{\mathrm{e}}$ & $2.22 \pm 0.68^{d}$ & $1.68 \pm 0.56^{b c}$ & $1.15 \pm 0.41^{\mathrm{a}}$ & $1.63 \pm 0.70^{\mathrm{bc}}$ & $2.27 \pm 0.84^{d}$ & $2.13 \pm 3.99^{d}$ & $2.02 \pm 0.51^{c d}$ & $1.51 \pm 0.53^{\mathrm{ab}}$ \\
\hline $\begin{array}{l}\text { Interval between } \\
\text { basal pair of lobes } \\
\text { (IBL) }\end{array}$ & & $2.24 \pm 0.67^{b}$ & $3.51 \pm 0.82^{c}$ & $2.51 \pm 0.72^{b}$ & $2.50 \pm 0.85^{b}$ & $2.70 \pm 0.78^{b}$ & $2.43 \pm 0.97^{b}$ & $2.53 \pm 0.97^{b}$ & $2.42 \pm 0.09^{b}$ & $2.58 \pm 0.65^{b}$ & $1.80 \pm 0.54^{\mathrm{a}}$ \\
\hline $\begin{array}{l}\text { Length of terminal } \\
\text { lobe (LTL) }\end{array}$ & & $0.36 \pm 0.14^{\mathrm{ab}}$ & $0.30 \pm 0.12^{\mathrm{a}}$ & $0.36 \pm 0.17^{a b}$ & $0.63 \pm 0.31^{c d}$ & $0.76 \pm 0.30^{d}$ & $0.75 \pm 0.41$ & $0.27 \pm 0.12^{\mathrm{a}}$ & $0.36 \pm 0.16^{b}$ & $0.70 \pm 0.42^{\mathrm{d}}$ & $0.49 \pm 0.14^{\mathrm{bc}}$ \\
\hline $\begin{array}{l}\text { Width of terminal } \\
\text { lobe (WTL) }\end{array}$ & & $0.40 \pm 0.19^{a}$ & $0.39 \pm 0.17^{a}$ & $0.59 \pm 0.23^{b c}$ & $0.62 \pm 0.29^{b c}$ & $0.64 \pm 0.22^{b c}$ & $0.77 \pm 0.39^{c}$ & $0.56 \pm 0.28^{\mathrm{ab}}$ & $0.60 \pm 0.23^{b c}$ & $0.71 \pm 0.25^{b c}$ & $0.56 \pm 0.22^{\mathrm{ab}}$ \\
\hline $\begin{array}{l}\text { Maximal depth of } \\
\text { sinus (SD) }\end{array}$ & & $1.15 \pm 0.36^{\mathrm{ab}}$ & $0.80 \pm 0.32^{\mathrm{a}}$ & $0.91 \pm 0.24^{\mathrm{a}}$ & $1.73 \pm 0.61^{c}$ & $2.8 \pm 0.69^{d}$ & $2.8 \pm 0.88^{d}$ & $0.83 \pm 0.26^{a}$ & $1.11 \pm 0.24^{\mathrm{ab}}$ & $1.33 \pm 0.58^{b}$ & $1.47 \pm 0.36^{\mathrm{bc}}$ \\
\hline $\begin{array}{l}\text { Maximal depth of } \\
\text { sinus (DPVS) }\end{array}$ & & $0.96 \pm 0.37^{c}$ & $1.66 \pm 0.30^{f}$ & $1.28 \pm 0.35^{\mathrm{de}}$ & $0.93 \pm 0.37^{c}$ & $0.40 \pm 0.23^{\mathrm{a}}$ & $0.66 \pm 0.32^{b}$ & $1.45 \pm 0.47^{\text {ef }}$ & $1.23 \pm 0.41^{\mathrm{d}}$ & $1.09 \pm 0.24^{\mathrm{cd}}$ & $0.63 \pm 0.28^{b}$ \\
\hline $\begin{array}{l}\text { Number of } \\
\text { primary } \\
\text { tooth/lobes (NPL) }\end{array}$ & & $14.6 \pm 2.82^{\mathrm{bc}}$ & $14.79 \pm 2.72^{\text {cd }}$ & $16.33 \pm 4.06^{\text {de }}$ & $14.07 \pm 2.29^{b c}$ & $13 \pm 1.98^{\mathrm{ab}}$ & $13.37 \pm 2.60^{\mathrm{abc}}$ & $17.60 \pm 3.99^{\mathrm{e}}$ & $16.70 \pm 2.40^{\mathrm{e}}$ & $12.05 \pm 1.87^{a}$ & $14.90 \pm 2.46^{c c}$ \\
\hline $\begin{array}{l}\text { Number of } \\
\text { secondary } \\
\text { tooth/lobes (NSL) }\end{array}$ & & $0.68 \pm 2.12^{\mathrm{ab}}$ & $0.0 \pm 0.0^{a}$ & $0.03 \pm 0.2^{\mathrm{a}}$ & $0.09 \pm 0.73^{a}$ & $1.23 \pm 2.49^{\mathrm{ab}}$ & $2.81 \pm 3.77^{c}$ & $0.0 \pm 0.0^{a}$ & $0.0 \pm 0.0^{a}$ & $0.0 \pm 0.0^{a}$ & $1.90 \pm 3.60^{\mathrm{bc}}$ \\
\hline
\end{tabular}

Table 2 Leaf morphological traits variation (in $\mathrm{cm}$ ) according to elevation for Q. calliprinos and Q. infectoria 
Q. calliprinos

\section{Elevation ( $m$ )}

$N$

Petiole length (PL)

Relative petiole length (RPL)

Leaf blade length (LL)

Leaf blade width at widest point (LW)

Interval between apical pair of sinuses (IAS)

Interval between basal pair of sinuses (IBS)

Nerve length in blade center (NLC)

Blade width in 0.1 length of blade from leaf base (W0.1)

Maximal depth of sinus (DPVS)

Interval between basal pair of lobes (IBL)

Interval between apical and basal lobe (IABL)

Interval between central nerve and apical leaf nerve

(ICALN)

Blade width 0.9 length of blade from leaf base (W0.9)

$\begin{array}{cccccccc}0-500 & 500-1000 & 1000-1500 & 1500-2000 & 0-500 & \mathbf{5 0 0 - 1 0 0 0} & \mathbf{1 0 0 0 - 1 5 0 0} & \mathbf{1 5 0 0 - 2 0 0 0} \\ 20 & 120 & 100 & 40 & 50 & 50 & 160 & 60 \\ 0.47 \pm 0.11^{\mathrm{b}} & 0.37 \pm 0.09^{\mathrm{a}} & 0.38 \pm 0.12^{\mathrm{a}} & 0.38 \pm 0.11^{\mathrm{a}} & 1.21 \pm 0.31^{\mathrm{b}} & 1.28 \pm 0.50^{\mathrm{b}} & 1.20 \pm 0.40^{\mathrm{b}} & 0.97 \pm 0.55^{\mathrm{a}} \\ 0.13 \pm 0.04^{\mathrm{b}} & 0.1 \pm 0.03^{\mathrm{a}} & 0.11 \pm 0.03^{\mathrm{a}} & 0.1 \pm 0.02^{\mathrm{a}} & 0.18 \pm 0.04 & 0.20 \pm 0.08 & 0.20 \pm 0.07 & 0.18 \pm 0.08 \\ 3.52 \pm 0.68 & 3.79 \pm 0.87 & 3.48 \pm 0.89 & 3.73 \pm 0.92 & 6.80 \pm 1.60^{\mathrm{c}} & 6.78 \pm 1.41^{\mathrm{c}} & 6.12 \pm 1.29^{\mathrm{b}} & 5.16 \pm 1.36^{\mathrm{a}} \\ 1.68 \pm 0.37^{\mathrm{a}} & 2.13 \pm 0.51^{\mathrm{c}} & 1.87 \pm 0.43^{\mathrm{ab}} & 1.94 \pm 0.63^{\mathrm{b}} & 3.66 \pm 0.9^{\mathrm{b}} & 3.55 \pm 0.7^{\mathrm{b}} & 3.07 \pm 0.7^{\mathrm{a}} & 2.82 \pm 0.77^{\mathrm{a}} \\ 0.00 & 0.00 & 0.00 & 0.00 & 0.94 \pm 0.46^{\mathrm{b}} & 0.81 \pm 0.22^{\mathrm{a}} & 0.75 \pm 0.26^{\mathrm{a}} & 0.80 \pm 0.32^{\mathrm{a}} \\ 0.00 & 0.00 & 0.00 & 0.00 & 2.85 \pm 0.76^{\mathrm{c}} & 2.44 \pm 0.60^{\mathrm{b}} & 2.07 \pm 0.62^{\mathrm{a}} & 1.86 \pm 0.57^{\mathrm{a}} \\ 0.94 \pm 0.21^{\mathrm{a}} & 1.21 \pm 0.29^{\mathrm{c}} & 1.08 \pm 0.26^{\mathrm{b}} & 1.08 \pm 0.36^{\mathrm{b}} & 2.27 \pm 0.53^{\mathrm{c}} & 2.16 \pm 0.45^{\mathrm{c}} & 1.97 \pm 0.45^{\mathrm{b}} & 1.76 \pm 0.50^{\mathrm{a}} \\ 1.16 \pm 0.29^{\mathrm{ab}} & 1.22 \pm 0.3^{\mathrm{b}} & 1.13 \pm 0.24^{\mathrm{ab}} & 1.05 \pm 0.36^{\mathrm{a}} & 2.11 \pm 0.70^{\mathrm{b}} & 2.17 \pm 0.54^{\mathrm{b}} & 1.67 \pm 0.46^{\mathrm{a}} & 1.52 \pm 0.52^{\mathrm{a}} \\ 0.00 & 0.00 & 0.00 & 0.00 & 1.55 \pm 0.41^{\mathrm{c}} & 1.46 \pm 0.32^{\mathrm{c}} & 1.22 \pm 0.34^{\mathrm{b}} & 1.06 \pm 0.34^{\mathrm{a}} \\ 0.00 & 0.00 & 0.00 & 0.00 & 3.13 \pm 0.79^{\mathrm{c}} & 2.74 \pm 0.66^{\mathrm{b}} & 2.36 \pm 0.69^{\mathrm{a}} & 2.19 \pm 0.67^{\mathrm{a}} \\ 1.65 \pm 1.74^{\mathrm{a}} & 2.46 \pm 1.62^{\mathrm{b}} & 2.28 \pm 1.64^{\mathrm{ab}} & 1.97 \pm 2.04^{\mathrm{ab}} & 4.93 \pm 1.37^{\mathrm{bc}} & 5.24 \pm 1.29^{\mathrm{c}} & 4.51 \pm 1.28^{\mathrm{b}} & 3.79 \pm 1.14^{\mathrm{a}} \\ 0.31 \pm 0.11^{\mathrm{a}} & 0.40 \pm 0.14^{\mathrm{b}} & 0.36 \pm 0.12^{\mathrm{ab}} & 0.36 \pm 0.1^{\mathrm{ab}} & 0.7 \pm 0.2^{\mathrm{b}} & 0.63 \pm 0.19^{\mathrm{ab}} & 0.66 \pm 0.2^{\mathrm{ab}} & 0.59 \pm 0.21^{\mathrm{a}} \\ 0.86 \pm 0.19^{\mathrm{a}} & 1.05 \pm 0.3^{\mathrm{b}} & 0.88 \pm 0.25^{\mathrm{a}} & 0.96 \pm 0.36^{\mathrm{ab}} & 1.70 \pm 0.55^{\mathrm{c}} & 1.61 \pm 0.51 \mathrm{~b}^{\mathrm{c}} & 1.47 \pm 0.41^{\mathrm{b}} & 1.23 \pm 0.56^{\mathrm{a}}\end{array}$

Mean values and standard deviation are shown. For each species, different letters in the same rows differ significantly $(p<0,05)$ 



\section{$P(\mathrm{~mm} /$ year $)$}

N

Petiole length (PL)

Relative petiole length (RPL)

Leaf blade length (LL)

Leaf blade width at widest point (LW)

Relative blade shape (RBS)

Interval between basal pair of sinuses (IBS)

Nerve length in blade center (NLC)

Interval between central nerve and apical leaf nerve (ICALN)

Blade width in 0.1 length of blade from leaf base (W0.1)

Maximal depth of sinus (DPVS)

Interval between basal pair of lobes (IBL)

Interval between apical pair of lobes (IAL)

Interval between apical and basal lobe (IABL)

Q. calliprinos

$\begin{array}{cccccccccc}300-600 & 600-800 & 800-1000 & 1000-1200 & 1200-1500 & 600-800 & 800-1000 & 1000-1200 & 1200-1500 \\ 20 & 60 & 40 & 80 & 80 & 30 & 70 & 120 & 100 \\ 0.44 \pm 0.13^{\mathrm{c}} & 0.35 \pm 0.09^{\mathrm{ab}} & 0.32 \pm 0.06^{\mathrm{a}} & 0.43 \pm 0.13^{\mathrm{c}} & 0.38 \pm 0.1^{\mathrm{b}} & 1.27 \pm 0.64 & 1.12 \pm 0.39 & 1.2 \pm 0.38 & 1.16 \pm 0.52 \\ 0.09 \pm 0.02 & 0.11 \pm 0.03^{\mathrm{b}} & 0.09 \pm 0.03 & 0.11 \pm 0.04 & 0.12 \pm 0.03 & 0.22 \pm 0.09 & 0.19 \pm 0.06 & 0.19 \pm 0.06 & 0.19 \pm 0.07 \\ 4.72 \pm 0.7^{\mathrm{c}} & 3.28 \pm 0.75^{\mathrm{a}} & 3.72 \pm 0.89^{\mathrm{b}} & 3.97 \pm 0.76^{\mathrm{b}} & 3.32 \pm 0.81^{\mathrm{a}} & 5.67 \pm 1^{\mathrm{a}} & 5.99 \pm 1.36^{\mathrm{a}} & 6.59 \pm 1.68^{\mathrm{b}} & 5.89 \pm 1.3^{\mathrm{a}} \\ 2.26 \pm 0.4^{\mathrm{c}} & 2.05 \pm 0.54^{\mathrm{bc}} & 1.94 \pm 0.55^{\mathrm{ab}} & 2.09 \pm 0.48^{\mathrm{bc}} & 1.77 \pm 0.44^{\mathrm{a}} & 3.03 \pm 0.65^{\mathrm{ab}} & 3.28 \pm 0.81^{\mathrm{bc}} & 3.43 \pm 0.87^{\mathrm{c}} & 2.9 \pm 0.65^{\mathrm{a}} \\ 2.13 \pm 0.35^{\mathrm{c}} & 1.64 \pm 0.31^{\mathrm{a}} & 1.96 \pm 0.31^{\mathrm{b}} & 1.94 \pm 0.33^{\mathrm{b}} & 1.92 \pm 0.41^{\mathrm{b}} & 1.91 \pm 0.33^{\mathrm{a}} & 1.85 \pm 0.23^{\mathrm{a}} & 1.94 \pm 0.36^{\mathrm{a}} & 2.06 \pm 0.26^{\mathrm{b}} \\ & & & & & 2.22 \pm 0.73^{\mathrm{b}} & 2.43 \pm 0.73^{\mathrm{b}} & 2.32 \pm 0.76^{\mathrm{b}} & 1.94 \pm 0.55^{\mathrm{a}} \\ 1.31 \pm 0.27^{\mathrm{c}} & 1.16 \pm 0.31^{\mathrm{b}} & 1.13 \pm 0.29^{\mathrm{b}} & 1.19 \pm 0.28^{\mathrm{b}} & 1 \pm 0.26^{\mathrm{a}} & 1.87 \pm 0.35^{\mathrm{a}} & 2.01 \pm 0.49^{\mathrm{ab}} & 2.15 \pm 0.54^{\mathrm{b}} & 1.9 \pm 0.47^{\mathrm{a}} \\ 0.5 \pm 0.2^{\mathrm{b}} & 0.36 \pm 0.14^{\mathrm{a}} & 0.36 \pm 0.09^{\mathrm{a}} & 0.39 \pm 0.13^{\mathrm{a}} & 0.34 \pm 0.09^{\mathrm{a}} & 0.58 \pm 0.16^{\mathrm{a}} & 0.63 \pm 0.17^{\mathrm{ab}} & 0.68 \pm 0.22^{\mathrm{b}} & 0.66 \pm 0.21^{\mathrm{b}} \\ 1.19 \pm 0.28 & 1.22 \pm 0.3 & 1.14 \pm 0.34 & 1.2 \pm 0.29 & 1.08 \pm 0.26 & 1.88 \pm 0.74^{\mathrm{b}} & 1.92 \pm 0.68^{\mathrm{b}} & 1.9 \pm 0.55^{\mathrm{b}} & 1.55 \pm 0.42^{\mathrm{a}} \\ & & & & & 1.3 \pm 0.35^{\mathrm{ab}} & 1.35 \pm 0.37^{\mathrm{bc}} & 1.39 \pm 0.44^{\mathrm{c}} & 1.12 \pm 0.29^{\mathrm{a}} \\ & & & & & 2.54 \pm 0.76^{\mathrm{b}} & 2.69 \pm 0.78^{\mathrm{b}} & 2.62 \pm 0.81^{\mathrm{b}} & 2.25 \pm 0.66^{\mathrm{a}} \\ 2.05 \pm 2.16^{\mathrm{a}} & 1.43 \pm 1.48^{\mathrm{a}} & 3.39 \pm 0.9^{\mathrm{b}} & 3.04 \pm 1.43^{\mathrm{b}} & 1.63 \pm 1.69^{\mathrm{a}} & 4.2 \pm 0.99 & 4.54 \pm 1.34 & 4.78 \pm 1.57 & 4.4 \pm 1.07\end{array}$

Table 4 Leaf morphological traits variation (in $\mathrm{cm}$ ) according to average annual precipitation (P) for $Q$. calliprinos and $Q$. infectoria

Mean values and standard deviation are shown. Different letters in the same row differ significantly $(p<0,05)$ 
Table 5 Mean and standard deviation values for measured fruit traits (in $\mathrm{cm}$ )

\begin{tabular}{|c|c|c|c|c|c|c|c|}
\hline Species & $N$ & Cupule length $C L$ & Fruit length FL & Cupule diameter $C D$ & Acorn diameter $A D$ & Peduncle length $P L$ & Scale length $S L$ \\
\hline Q. calliprinos & 101 & $1.68 \pm 0.33^{\mathrm{bc}}$ & $2.73 \pm 0.42^{\mathrm{ab}}$ & $2.02 \pm 0.38^{\mathrm{ab}}$ & $1.47 \pm 0.28^{\mathrm{a}}$ & $0.68 \pm 0.41^{\text {cd }}$ & $0.39 \pm 0.11^{\mathrm{ab}}$ \\
\hline Q. look & 47 & $2.02 \pm 0.59$ de & $3.00 \pm 0.56^{b c}$ & $2.72 \pm 0.60^{d}$ & $2.21 \pm 0.5^{c}$ & $0.33 \pm 0.42^{\mathrm{abc}}$ & $0.48 \pm 0.16^{b}$ \\
\hline Q. infectoria & 128 & $1.36 \pm 0.40^{\mathrm{a}}$ & $3.53 \pm 0.83^{\mathrm{de}}$ & $1.80 \pm 0.25^{\mathrm{a}}$ & $1.48 \pm 0.23^{\mathrm{a}}$ & $0.73 \pm 0.51^{d}$ & - \\
\hline Q. ithaburensis & 84 & $2.34 \pm 0.45^{f}$ & $4.44 \pm 0.61^{g}$ & $3.25 \pm 0.62^{\mathrm{e}}$ & $2.01 \pm 0.30^{b}$ & $0.42 \pm 0.70^{\mathrm{abcb}}$ & $1.13 \pm 1.01^{\mathrm{c}}$ \\
\hline Q. cedrorum & 36 & $1.32 \pm 0.45^{\mathrm{a}}$ & $2.48 \pm 0.55^{\mathrm{a}}$ & $1.79 \pm 0.40^{\mathrm{a}}$ & $1.52 \pm 0.29^{a}$ & $0.49 \pm 0.47^{\mathrm{abcd}}$ & - \\
\hline Q. kotschyana & 58 & $1.22 \pm 0.24^{\mathrm{a}}$ & $3.14 \pm 0.55^{\mathrm{bcd}}$ & $2.17 \pm 0.30^{b}$ & $2.00 \pm 0.29^{b}$ & $0.43 \pm 0.31^{\mathrm{abcd}}$ & - \\
\hline Q. cerris & 99 & $2.21 \pm 0.35^{\mathrm{ef}}$ & $3.17 \pm 0.56^{c d}$ & $2.86 \pm 0.35^{d}$ & $2.09 \pm 0.31^{b c}$ & $0.65 \pm 0.72^{\mathrm{cd}}$ & $0.87 \pm 0.25^{c}$ \\
\hline Q. infectoria $\times$ ithaburensis & 8 & $1.63 \pm 0.60^{\mathrm{b}}$ & $4.02 \pm 0.63^{f}$ & $2.45 \pm 0.51^{c}$ & $1.93 \pm 0.29^{b}$ & $0.61 \pm 0.73^{b c d}$ & - \\
\hline Q. infectoria $\times$ look & 10 & $1.90 \pm 0.19^{\mathrm{cd}}$ & $2.95 \pm 0.24^{b c}$ & $1.82 \pm 0.22^{\mathrm{a}}$ & $1.49 \pm 0.13^{a}$ & $0.23 \pm 0.20^{\mathrm{a}}$ & $0.33 \pm 0.06^{a}$ \\
\hline Q. cerris $\times$ cedrorum & 6 & $2.93 \pm 0.29 g$ & $3.73 \pm 0.45^{e f}$ & $3.28 \pm 0.27^{e}$ & $2.27 \pm 0.26^{c}$ & $0.13 \pm 0.34^{a}$ & $1.05 \pm 0.19^{c}$ \\
\hline
\end{tabular}

$y(p<0,05)$

Table 6 Fruit trait mean values (in $\mathrm{cm}$ ) of our samples of $Q$. ithaburensis and those of $Q$. ithaburensis subsp ithaburensis and $Q$. ithaburensis subsp macrolepis from Dufour-Dror Ertaş (2002)

$\begin{array}{lccc}\text { Morphological trait } & \text { Fruit length FL } & \text { Cupule diameter CD } & \text { Scale length SL } \\ \text { Q. ithaburensis (samples from Lebanon) } & 4.44^{\mathrm{a}} & 3.25^{\mathrm{a}} & 1.13^{\mathrm{b}} \\ \text { Q. ithaburensis subsp ithaburensis } & 4.8^{\mathrm{b}} & 3.4^{\mathrm{a}} & 0.9^{\mathrm{a}} \\ \text { Q. ithaburensis subsp macrolepis } & 4.4^{\mathrm{a}} & 5.2^{\mathrm{b}} & 1.9^{\mathrm{c}}\end{array}$

Different letters in the same column differ significantly $(p<0,05)$ 

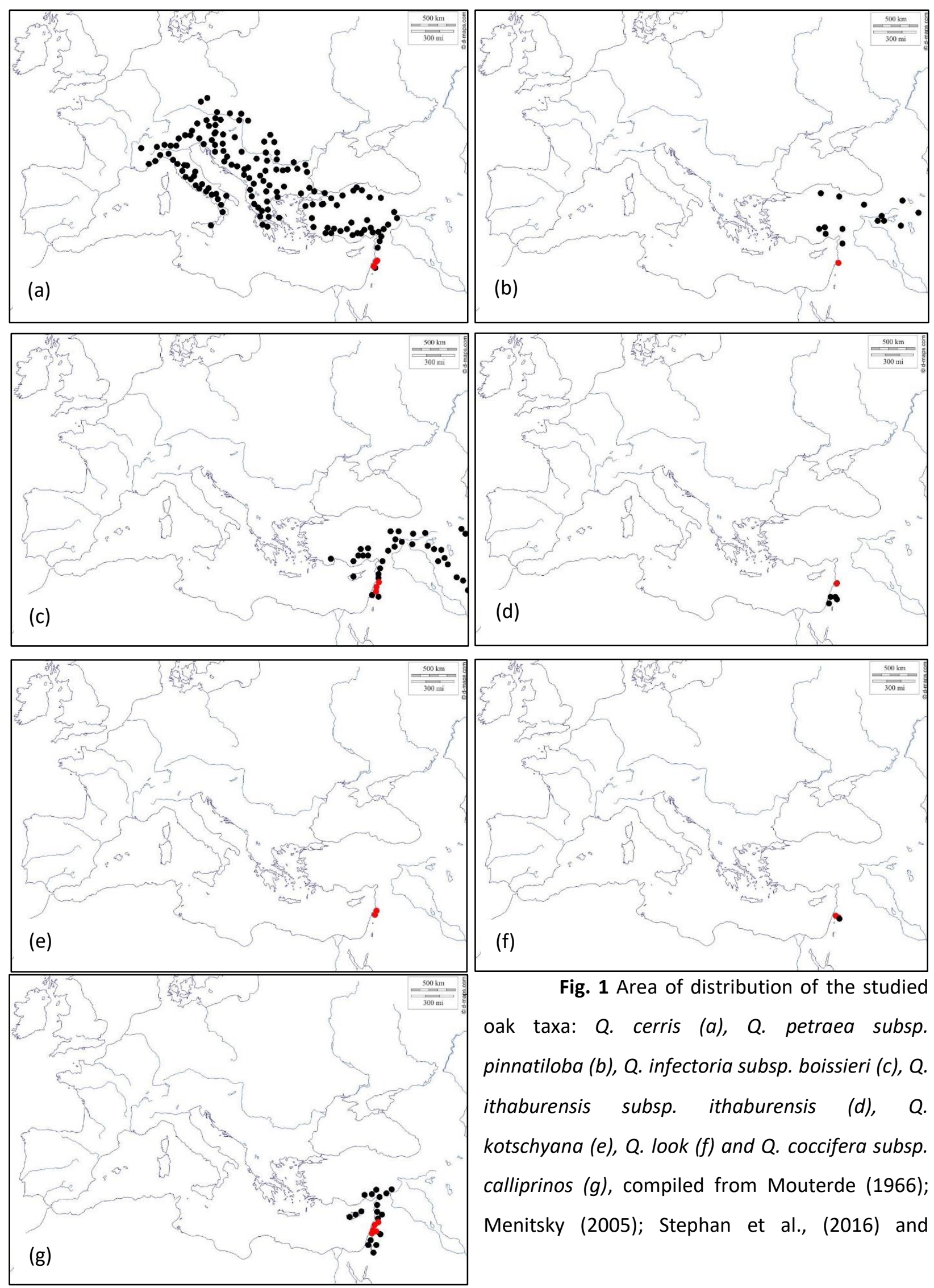

Fig. 1 Area of distribution of the studied oak taxa: Q. cerris (a), Q. petraea subsp. pinnatiloba (b), Q. infectoria subsp. boissieri (c), $Q$. ithaburensis subsp. ithaburensis (d), $Q$. kotschyana (e), Q. look (f) and Q. coccifera subsp. calliprinos (g), compiled from Mouterde (1966); Menitsky (2005); Stephan et al., (2016) and 


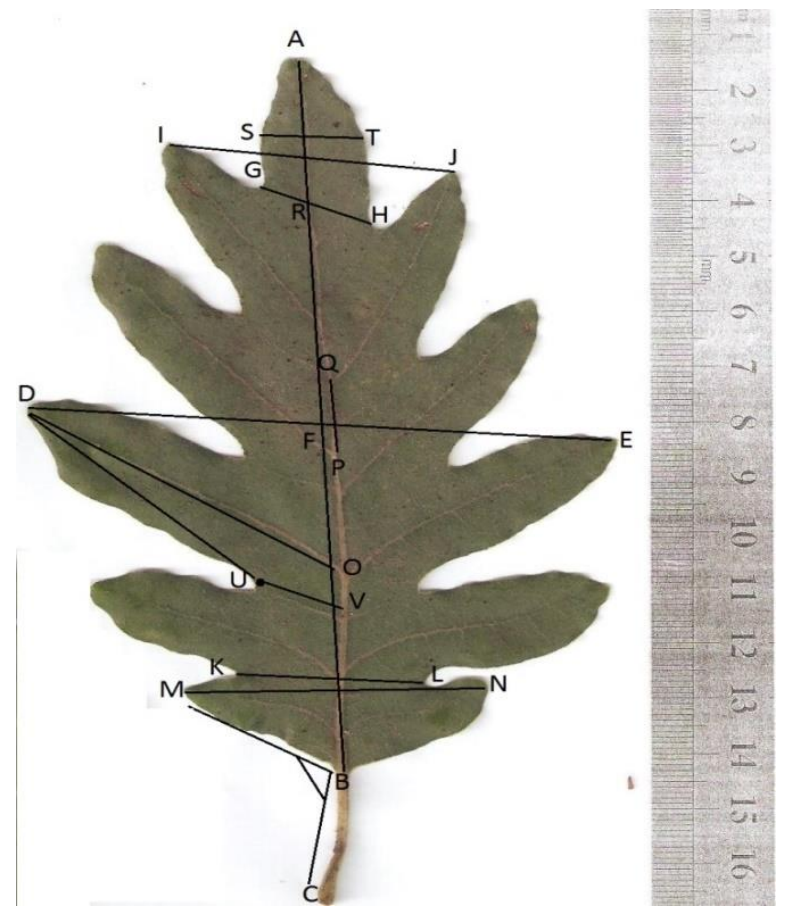

Fig. 2 Measurements represented on $Q$. kotschyana leaf

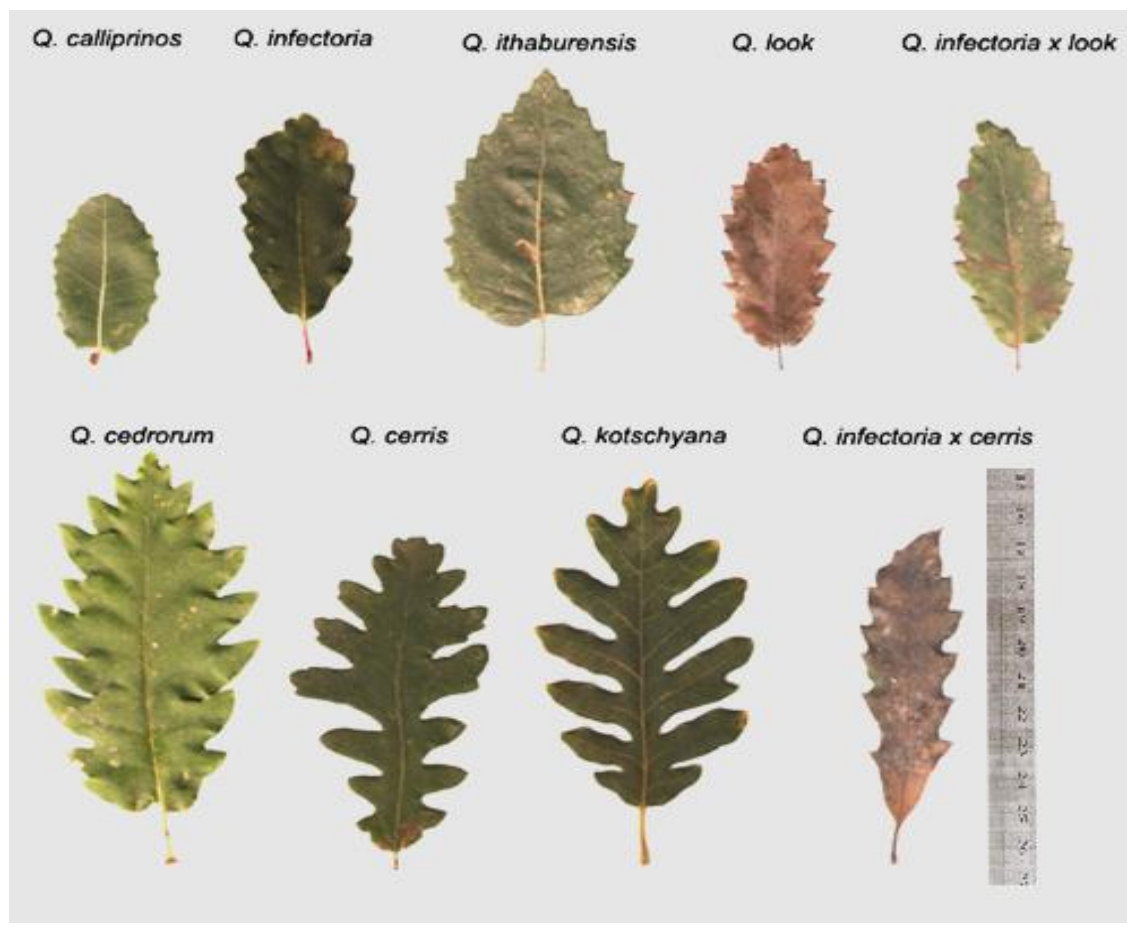


Fig. 3 Scanned leaves of different oak taxa

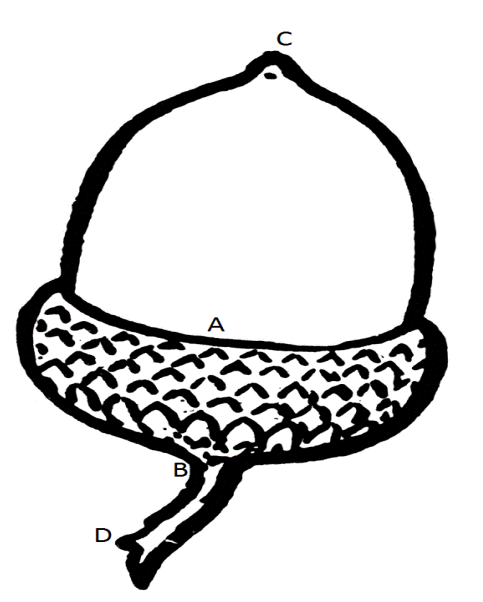

1- $A B$ : Length of cupule

2- $C B$ : Length of fruit (acorn plus cupule)

3- CD: Cupule diameter

4- AD: Acorn diameter

5- BD: Length of peduncle

6- SL: Scale length (if scales are protruding)

Fig. 4 Measurements represented on a drawing of an acorn

Fig. 5 Biplot after Varimax rotation of all variables and their respective contribution 


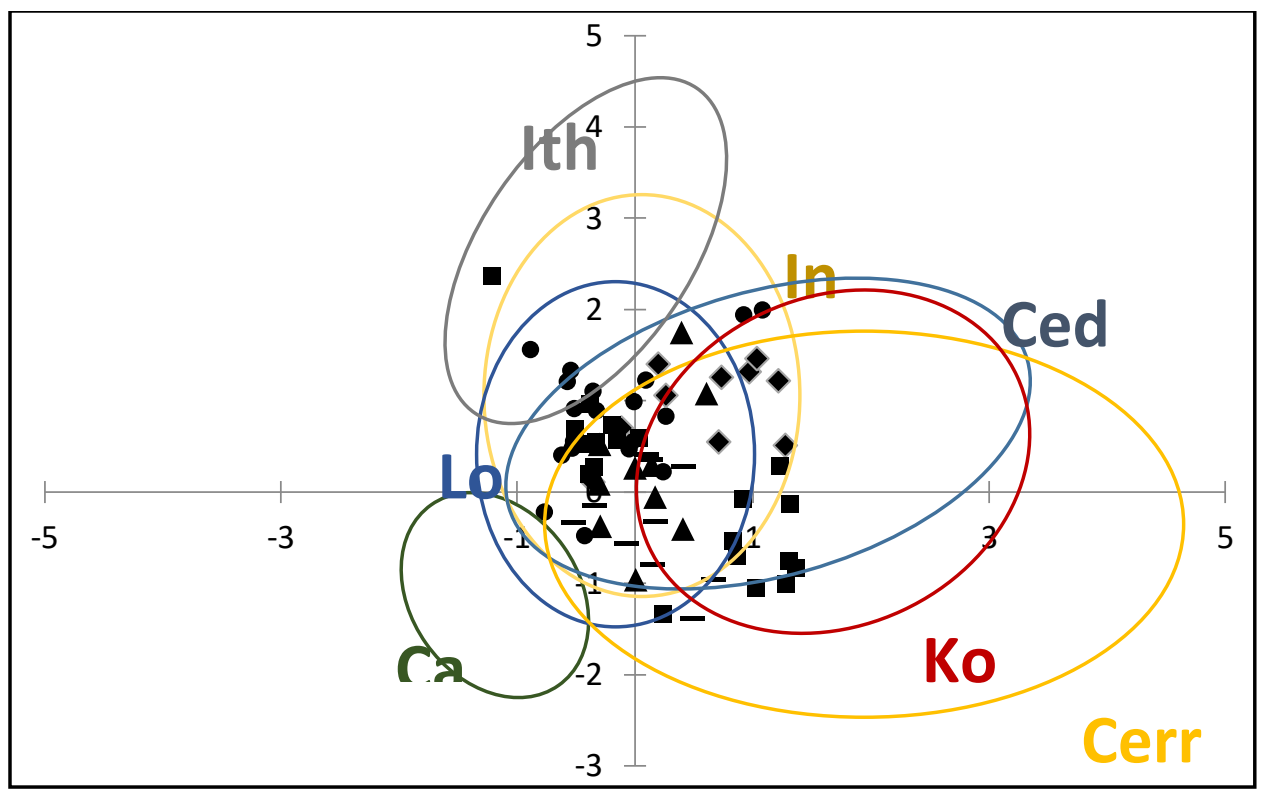

Fig. 6 Biplot of Observations after Varimax rotation of leaf traits. Note: black symbols for hybrids: $(\bullet)=Q$. infectoria $\times$ Q. ithaburensis; $(\mathbf{\square})=Q$. infectoria $\times$ cerris; $(\mathbf{\Delta})=Q$. infectoria $\times$ look; $Q$. cerris $\times$ cedrorum. For the circles codes: Q. calliprinos (Ca), Q. cerris (Cerr), Q. cedrorum (Ced), Q. infectoria (In), Q. ithaburensis (Ith), Q. look (Lo) and Q. kotschyana (Ko).

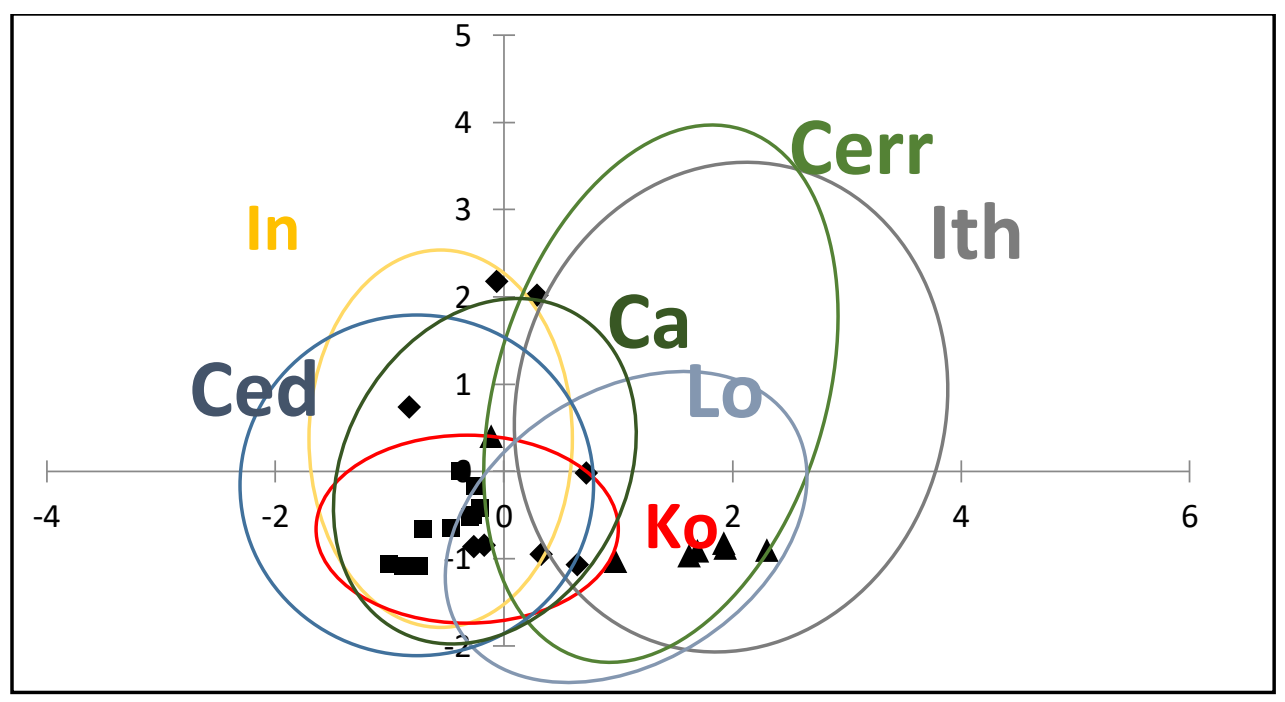

Fig. 7 Biplot of Observations after Varimax rotation of fruit traits. Note: black symbols for hybrids: $(\mathbf{\square})=Q$. infectoria $\times$ look; $(\boldsymbol{\Delta})=$ Q. cerris $\times$ cedrorum; $(\bullet)$ Q. infectoria $\times$ ithaburensis. For the circles codes: $Q$. calliprinos (Ca), Q. cerris (Cerr), Q. cedrorum (Ced), Q. infectoria (In), Q. ithaburensis (Ith), Q. look (Lo) and Q. kotschyana (Ko). 


\section{SUPPLEMENTARY MATERIAL}

Table A.1 Range of bioclimatic parameters values for the seven oak species in Lebanon

\begin{tabular}{|c|c|c|c|c|c|c|}
\hline Species & $\mathrm{N}$ sites & Elevation (m) & $\mathbf{Q}$ & $P(\mathrm{~mm})$ & $\operatorname{Tmax}\left({ }^{\circ} \mathrm{C}\right)$ & $\operatorname{Tmin}\left({ }^{\circ} \mathrm{C}\right)$ \\
\hline Q. calliprinos & 14 & $74-1745$ & $22-214$ & 191-1491 & $23.4-34.2$ & $-0.4-10.5$ \\
\hline Q. infectoria & 12 & $177-1811$ & $39-214$ & $412-1471$ & $22.8-36.1$ & $-4.2-10.3$ \\
\hline Q. cerris & 8 & $664-1634$ & 174-209 & $1295-1471$ & $23.4-31.1$ & $-0.4-5.5$ \\
\hline Q. look & 5 & $1516-1808$ & $88-202$ & 979-1371 & $23.4-34.6$ & $-0.4-4.20$ \\
\hline Q. ithaburensis & 5 & $182-592$ & $111-177$ & $782-1099$ & $29-32.3$ & $7.7-8.3$ \\
\hline Q. cedrorum & 5 & $1450-1766$ & $202-210$ & $1371-1471$ & $23.4-28$ & $-0.4-3.7$ \\
\hline Q. kotschyana & 5 & $1591-1902$ & 119-202 & 899-1371 & $22.8-23.4$ & $-4.0--0.4$ \\
\hline
\end{tabular}

Table A.2 Geographical coordinates of sampling locations of the different taxa

\begin{tabular}{|c|c|c|c|c|}
\hline Species & Location & $\mathrm{N}$ & $\mathrm{E}$ & Elevation(m) \\
\hline Q. look & Barqa & $34^{\circ} 12.103^{\prime}$ & $36^{\circ} 08,237^{\prime}$ & 1808 \\
\hline Q. look & Jabal El Shaykh & $33^{\circ} 27,229^{\prime}$ & $35^{\circ} 52,722^{\prime}$ & 1560 \\
\hline Q. look & Ain Zhalta & $33^{\circ} 44,531^{\prime}$ & $35^{\circ} 44,034^{\prime}$ & 1645 \\
\hline Q. look & Maasir El Shouf (east) & $33^{\circ} 40,145^{\prime}$ & $35^{\circ} 42,706^{\prime}$ & 1670 \\
\hline Q. look & Maasir El Shouf (west) & $33^{\circ} 40,273^{\prime}$ & $35^{\circ} 41,774^{\prime}$ & 1826 \\
\hline Q. look & Yanta-Deir el Achayer & $33^{\circ} 34,609^{\prime}$ & $35^{\circ} 57,333^{\prime}$ & 1610 \\
\hline Q. calliprinos & Annaya & $34^{\circ} 07,301^{\prime}$ & $35^{\circ} 45,229^{\prime}$ & 1166 \\
\hline Q. calliprinos & Ehmej & $34^{\circ} 07,530^{\prime}$ & $35^{\circ} 46,319^{\prime}$ & 1272 \\
\hline Q. calliprinos & Ehden & $34^{\circ} 18,599^{\prime}$ & $35^{\circ} 59,215^{\prime}$ & 1502 \\
\hline Q. calliprinos & Tannourine & $34^{\circ} 12,476^{\prime}$ & $35^{\circ} 55,522^{\prime}$ & 1745 \\
\hline Q. calliprinos & Beshwet & $34^{\circ} 08,753^{\prime}$ & $36^{\circ} 08,135^{\prime}$ & 1183 \\
\hline Q. calliprinos & Anjar & $33^{\circ} 44^{\prime} 0.47^{\prime \prime}$ & $35^{\circ} 57^{\prime} 7.90^{\prime \prime}$ & 992 \\
\hline Q. calliprinos & Hebariye & $33^{\circ} 22,118^{\prime}$ & $35^{\circ} 40,754^{\prime}$ & 599 \\
\hline Q. calliprinos & Jabal Moussa & $34^{\circ} 03,408^{\prime}$ & $35^{\circ} 46,621^{\prime}$ & 1467 \\
\hline Q. calliprinos & Tarchich & $33^{\circ} 53,025^{\prime}$ & $35^{\circ} 48,306^{\prime}$ & 1381 \\
\hline Q. calliprinos & Al Qourayet- Rahbe & $34^{\circ} 29,133^{\prime}$ & $36^{\circ} 09,080^{\prime}$ & 899 \\
\hline Q. calliprinos & Hamat & $34^{\circ} 18,185^{\prime}$ & $35^{\circ} 41,155^{\prime}$ & 177 \\
\hline Q. calliprinos & Wadi Jezzine & $33^{\circ} 32,845^{\prime}$ & $35^{\circ} 34,923^{\prime}$ & 800 \\
\hline Q. calliprinos & Hermel & $34^{\circ} 27.825^{\prime}$ & $36^{\circ} 23.383^{\prime}$ & 850 \\
\hline Q. calliprinos & Hermon & $33^{\circ} 31,115^{\prime}$ & $35^{\circ} 48,501^{\prime}$ & 988 \\
\hline Q. cedrorum & Jaj & $34^{\circ} 08,993^{\prime}$ & $35^{\circ} 49,388^{\prime}$ & 1606 \\
\hline Q. cedrorum & Ehden forest & $34^{\circ} 18,010^{\prime}$ & $35^{\circ} 59,363^{\prime}$ & 1861 \\
\hline Q. cedrorum & Ehden entrance & $34^{\circ} 18,795^{\prime}$ & $35^{\circ} 59,179^{\prime}$ & 1450 \\
\hline Q. cedrorum & Tannourine & $34^{\circ} 12,515^{\prime}$ & $35^{\circ} 55,684^{\prime}$ & 1766 \\
\hline
\end{tabular}




\begin{tabular}{|c|c|c|c|c|}
\hline Species & Location & $\mathrm{N}$ & $\mathrm{E}$ & Elevation(m) \\
\hline Q. cedrorum & Tannourine entrance & $34^{\circ} 12,587^{\prime}$ & $35^{\circ} 55,651^{\prime}$ & 1717 \\
\hline Q. cerris & Annaya & $34^{\circ} 07,301^{\prime}$ & $35^{\circ} 45,229^{\prime}$ & 1166 \\
\hline Q. cerris & Jaj & $34^{\circ} 08,944^{\prime}$ & $35^{\circ} 49,480^{\prime}$ & 1618 \\
\hline Q. cerris & Jaj & $34^{\circ} 09,440^{\prime}$ & $35^{\circ} 49,351^{\prime}$ & 1385 \\
\hline Q. cerris & Ehden & $34^{\circ} 18,805^{\prime}$ & $35^{\circ} 59,089^{\prime}$ & 1434 \\
\hline Q. cerris & Jabal Moussa & $34^{\circ} 03,444^{\prime}$ & $35^{\circ} 46,438^{\prime}$ & 1500 \\
\hline Q. cerris & Tarchich & $33^{\circ} 52,949^{\prime}$ & $35^{\circ} 49,016^{\prime}$ & 1533 \\
\hline Q. cerris & Hasbaya el maten & $33^{\circ} 52,799^{\prime}$ & $35^{\circ} 42,814^{\prime}$ & 664 \\
\hline Q. cerris & Bkassine & $33^{\circ} 33,416^{\prime}$ & $35^{\circ} 33,656^{\prime}$ & 1028 \\
\hline Q. cerris & Qmamine & $34^{\circ} 25,289^{\prime}$ & $36^{\circ} 07,571^{\prime}$ & 1403 \\
\hline Q. cerris & Jayroun & $34^{\circ} 25,889^{\prime}$ & $36^{\circ} 07,099^{\prime}$ & 1152 \\
\hline Q. cerris & Ain majdalayn & $33^{\circ} 30,913^{\prime}$ & $35^{\circ} 36,460^{\prime}$ & 1510 \\
\hline Q. cerris & Ehmej & $34^{\circ} 07,473^{\prime}$ & $35^{\circ} 48,313^{\prime}$ & 1277 \\
\hline Q. infectoria & Lehfed & $34^{\circ} 09,689^{\prime}$ & $35^{\circ} 47,187^{\prime}$ & 1046 \\
\hline Q. infectoria & Ehmej & $34^{\circ} 07,473^{\prime}$ & $35^{\circ} 48,313^{\prime}$ & 1277 \\
\hline Q. infectoria & Ehden & $34^{\circ} 18,805^{\prime}$ & $35^{\circ} 59,089^{\prime}$ & 1434 \\
\hline Q. infectoria & Knaywer & $34^{\circ} 15,716^{\prime}$ & $35^{\circ} 55,611^{\prime}$ & 1331 \\
\hline Q. infectoria & Tannourine & $34^{\circ} 12,486^{\prime}$ & $35^{\circ} 56,032^{\prime}$ & 1811 \\
\hline Q. infectoria & Aita El Fekhar & $33^{\circ} 38,132^{\prime}$ & $35^{\circ} 54,621^{\prime}$ & 1300 \\
\hline Q. infectoria & Tarchich & $33^{\circ} 52,877^{\prime}$ & $35^{\circ} 48,240^{\prime}$ & 1426 \\
\hline Q. infectoria & Bkassine & $33^{\circ} 33,416^{\prime}$ & $35^{\circ} 33,656^{\prime}$ & 1028 \\
\hline Q. infectoria & Jabal Moussa & $34^{\circ} 03,432^{\prime}$ & $35^{\circ} 46,518^{\prime}$ & 1489 \\
\hline Q. infectoria & Wadi Jezzine & $33^{\circ} 32,845^{\prime}$ & $35^{\circ} 34,923^{\prime}$ & 800 \\
\hline Q. infectoria & Hamat & $34^{\circ} 18,185^{\prime}$ & $35^{\circ} 41,155^{\prime}$ & 177 \\
\hline Q. infectoria & Rmeich & $33^{\circ} 4,375^{\prime}$ & $35^{\circ} 21,913^{\prime}$ & 597 \\
\hline Q. infectoria & Ain majdalain & $33^{\circ} 30,913^{\prime}$ & $35^{\circ} 36,460^{\prime}$ & 1510 \\
\hline Q. infectoria & Hebariye & $33^{\circ} 22,118^{\prime}$ & $35^{\circ} 40,754^{\prime}$ & 599 \\
\hline Q. infectoria & Andqet & $34^{\circ} 37,423^{\prime}$ & $36^{\circ} 13,760^{\prime}$ & 295 \\
\hline Q. infectoria & Sfeinet Al Dreib & $34^{\circ} 33,953^{\prime}$ & $36^{\circ} 09,825^{\prime}$ & 313 \\
\hline Q. infectoria & Bar2a & $34^{\circ} 12.103^{\prime}$ & $36^{\circ} 08,237^{\prime}$ & 1807 \\
\hline Q. ithaburensis & Andqet & $34^{\circ} 36,020^{\prime}$ & $36^{\circ} 18,595^{\prime}$ & 597 \\
\hline Q. ithaburensis & Menjiz & $34^{\circ} 37,423^{\prime}$ & $36^{\circ} 13,760^{\prime}$ & 295 \\
\hline Q. ithaburensis & Noura & $34^{\circ} 37,362^{\prime}$ & $36^{\circ} 10,627^{\prime}$ & 182 \\
\hline Q. ithaburensis & Sfeinet Al Dreib & $34^{\circ} 33,953^{\prime}$ & $36^{\circ} 09,825^{\prime}$ & 313 \\
\hline Q. ithaburensis & Dhour Mart Moura & $34^{\circ} 35,039^{\prime}$ & $36^{\circ} 16,443^{\prime}$ & 684 \\
\hline Q. kotschyana & Jaj & $34^{\circ} 08,910^{\prime}$ & $35^{\circ} 49,599^{\prime}$ & 1621 \\
\hline Q. kotschyana & Akoura & $34^{\circ} 05,074^{\prime}$ & $35^{\circ} 56,679^{\prime}$ & 1886 \\
\hline Q. kotschyana & Ehden forset & $34^{\circ} 17,797^{\prime}$ & $35^{\circ} 59,321^{\prime}$ & 1918 \\
\hline Q. kotschyana & Bsharre & $34^{\circ} 14,669^{\prime}$ & $36^{\circ} 02,902^{\prime}$ & 1902 \\
\hline Q. kotschyana & Tannourine forest & $34^{\circ} 12,590^{\prime}$ & $35^{\circ} 55,640^{\prime}$ & 1714 \\
\hline Q. kotschyana & Jabal El Fuwwar & $33^{\circ} 54,214^{\prime}$ & $35^{\circ} 50,471^{\prime}$ & 1733 \\
\hline Q. infectoria $\times$ ithaburensis & Aaqbet Rachaya & $33^{\circ} 31,115^{\prime}$ & $35^{\circ} 48,501^{\prime}$ & 988 \\
\hline
\end{tabular}




\begin{tabular}{l|lllr} 
Species & Location & N & E & Elevation $(m)$ \\
\hline Q. infectoria x look & Ain Zhalta forest & $33^{\circ} 44,558^{\prime}$ & $35^{\circ} 43,983^{\prime}$ & 1630 \\
Q. infectoria x cerris & Jabal Moussa & $34^{\circ} 03,417^{\prime}$ & $35^{\circ} 46,539^{\prime}$ & 1480 \\
Q. cerris $x$ cedrorum & Jaj & $34^{\circ} 08,977^{\prime}$ & $35^{\circ} 49,641^{\prime}$ & 1640
\end{tabular}


Table A.3 Contribution in \% after Varimax Rotation for leaf traits and environmental gradients

\begin{tabular}{|c|c|c|}
\hline & D1 & D2 \\
\hline Elevation(m) & 0.7995 & 5.3574 \\
\hline Slope (\%) & 0.0658 & 0.0069 \\
\hline Soil depth(cm) & 0.3595 & 7.0708 \\
\hline Aspect (degree) & 0.0000 & 0.3718 \\
\hline Distance from the sea (m) DFS & 0.6190 & 0.6976 \\
\hline Precipitation (mm) & 1.5922 & 4.4807 \\
\hline Leaf blade length LL & 8.3565 & 0.3448 \\
\hline Petiole length PL & 2.0353 & 8.0500 \\
\hline Leaf blade width at widest point LW & 7.5539 & 1.3351 \\
\hline Distance between widest point and leaf base WB & 7.2565 & 0.0077 \\
\hline Interval between apical pair of sinuses IAS & 6.1597 & 2.0206 \\
\hline Interval between apical pair of lobes IAL & 7.1621 & 1.0365 \\
\hline Interval between basal pair of sinuses IBS & 1.9975 & 13.6450 \\
\hline Interval between basal pair of lobes IBL & 4.1156 & 9.5083 \\
\hline Interval between apical and basal lobe IABL & 7.1623 & 0.2527 \\
\hline Nerve length in blade center NLC & 7.9051 & 1.2838 \\
\hline Interval between central nerve and apical leaf nerve ICALN & 6.1990 & 0.1681 \\
\hline Blade width in 0.1 length of blade from leaf base W0.1 & 2.4950 & 9.7051 \\
\hline Blade width 0.9 length of blade from leaf base W0.9 & 0.1387 & 0.0047 \\
\hline Angle of the base of leaf blade An (degree) & 1.9593 & 0.4146 \\
\hline Length of terminal lobe LTL & 6.4181 & 0.0017 \\
\hline Width of terminal lobe WTL & 6.3520 & 0.8939 \\
\hline Maximal depth of sinus SD & 8.1214 & 0.2158 \\
\hline Maximal depth of sinus DPVS & 1.1213 & 13.7266 \\
\hline Number of primary tooth/lobes NPL & 0.0055 & 0.1990 \\
\hline Number of secondary tooth/lobes NSL & 1.4842 & 1.3196 \\
\hline Relative petiole length RPL & 0.0303 & 9.0938 \\
\hline Relative blade shape RBS & 0.0013 & 2.1319 \\
\hline
\end{tabular}


Table A.4 Contribution in \% after Varimax rotation of fruit traits

Fruit traits $(\mathrm{mm})$

Cupule length $\mathbf{C L}$

Fruit length FL

Cupule diameter CD

Acorn diameter AD

Peduncle length PL

Scale length SL
F1

22.7354

12.9001

28.5986

19.5402

0.2165

16.0092
F2

0.9455

0.6259

0.9132

2.0118

95.3322

0.1714 


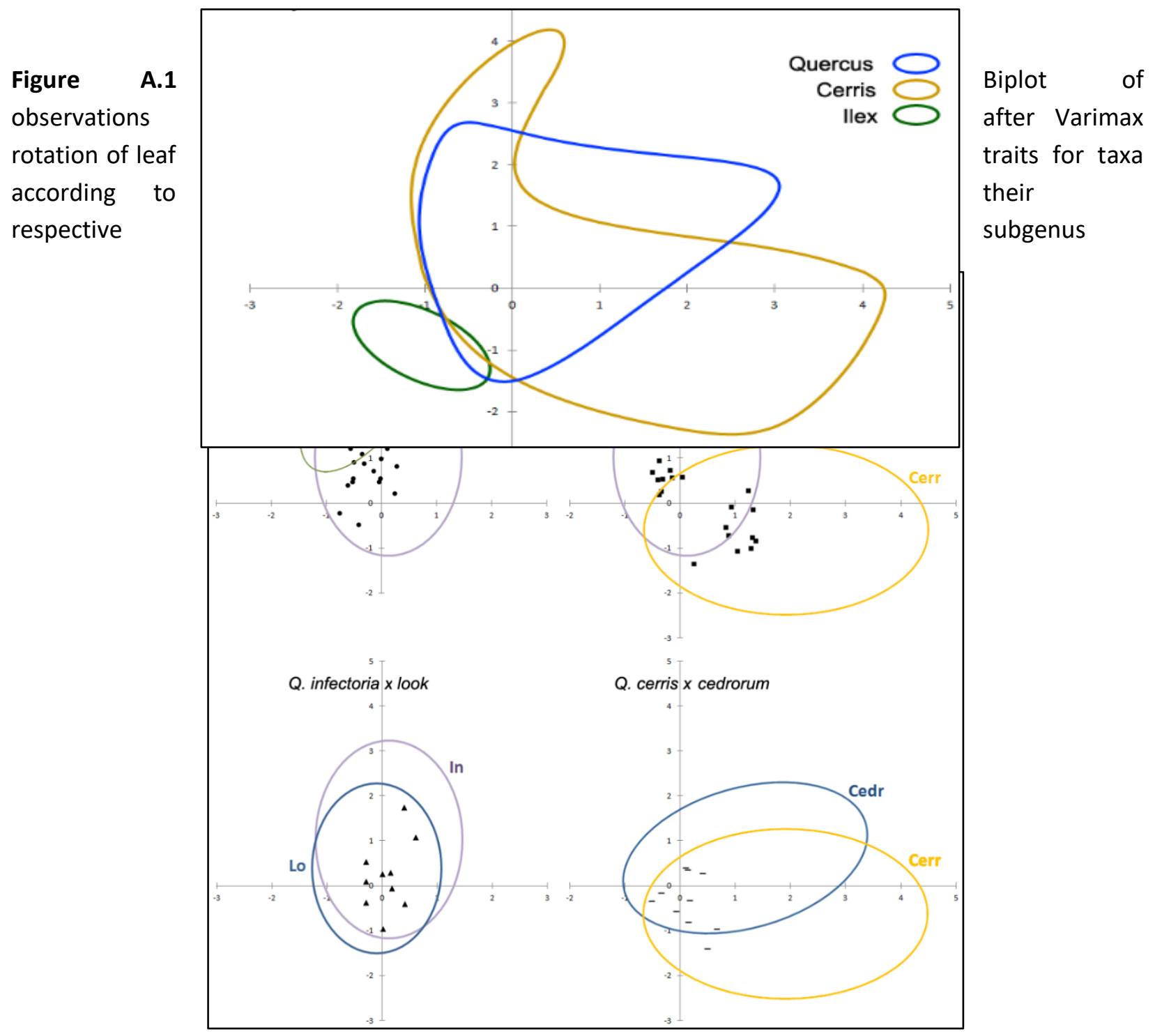

Figure A.2 Biplot of Observations after Varimax rotation of leaf traits for hybrids and their suggested parents. The contribution of each parent to the leaf morphology is retrievable from the position of the dots (hybrid trees) with respect to the ellipses. Indeed, in the upper-left case ( $Q$. infectoria $x$ ithaburensis) there is a major affinity between the hybrid and one parent ( $Q$. infectoria), while in the bottom-left example such an affinity is unclear (given the overlapped ellipses of the parents). 


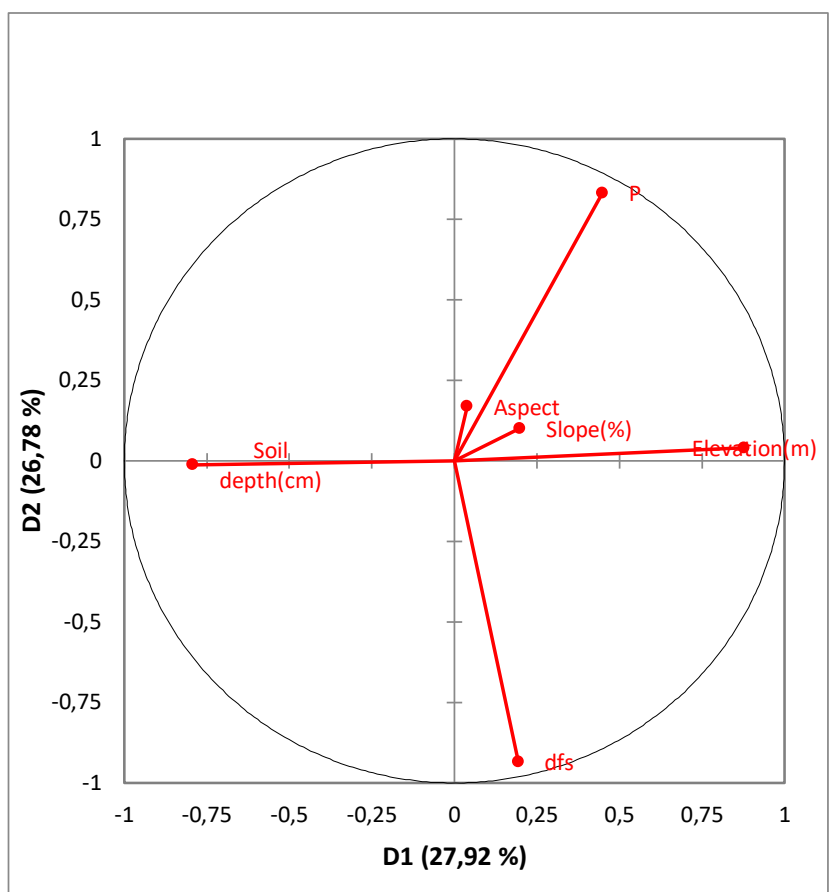

Figure A.3 Biplot after Varimax rotation for environmental variables. Total explained variance is $54.70 \%$; $P$ and dfs mean Precipitation and Distance from the Sea, respectively.

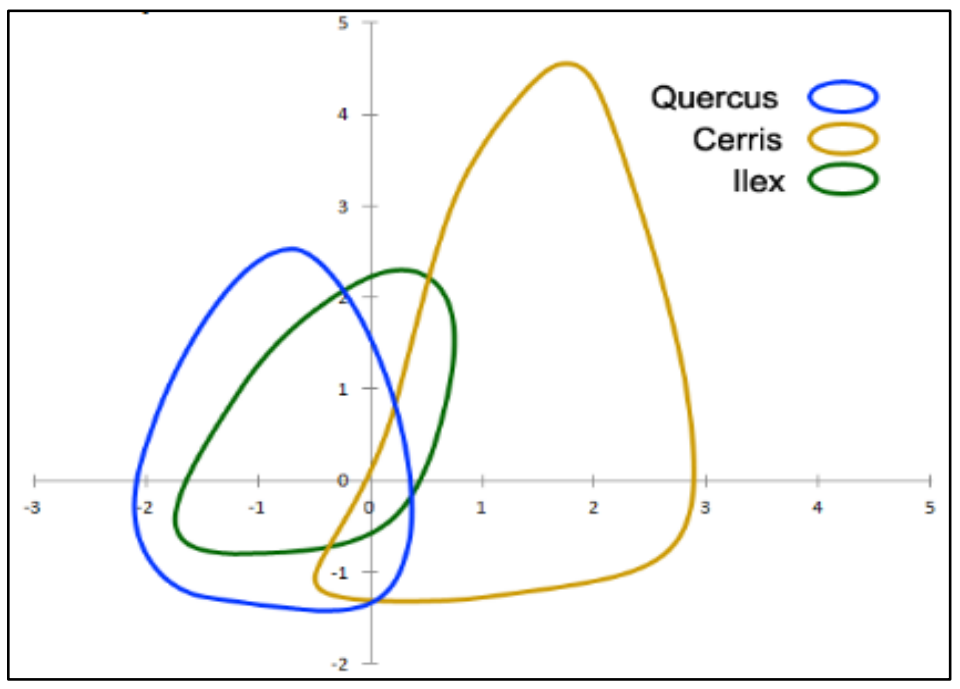

Figure A.4 Biplot of Observations after Varimax rotation of fruit traits for taxa according to their respective subgenus 


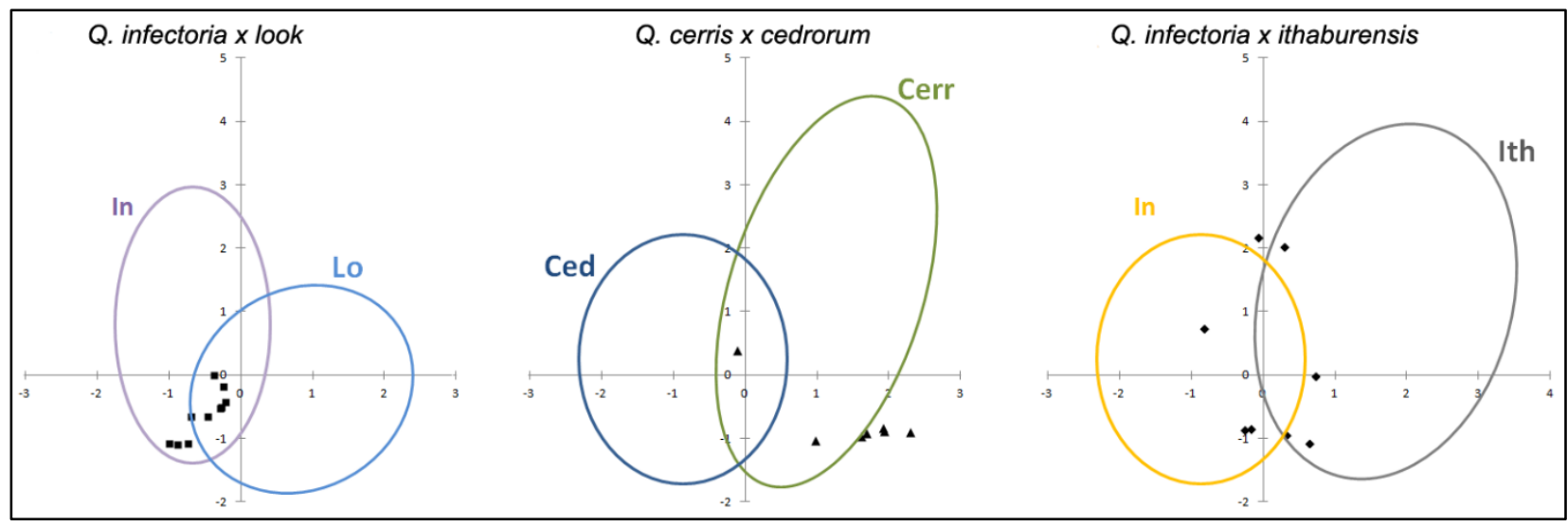

Figure A.5 Biplot of Observations after Varimax rotation of fruit traits for hybrids and their suggested parents. As for Fig. A.2 the relative position of dots representing hybrid trees can be related with a degree of affinity with parents, drawn with ellipses. 